\title{
Environmental conditions limit the distribution of Lepidurus arcticus (Branchiopoda, Notostraca) in lakes on the Hardangervidda mountain plateau, Southern Norway
}

\author{
Tore Qvenild' and Trygve Hesthagen ${ }^{2}$
}

Qvenild T and Hesthagen T. 2019. Environmental conditions limit the distribution of Lepidurus arcticus (Branchiopoda, Notostraca) in lakes on the Hardangervidda mountain plateau, Southern Norway.Fauna norvegica 39: 77-110.

The Arctic tadpole shrimp Lepidurus arcticus has a circumpolar distribution where the Hardangervidda mountain plateau in Norway marks its southernmost limit. Within this area, we searched for $L$. arcticus in 238 lakes in 27 catchments. On Hardangervidda, the distribution pattern of $L$. arcticus is highly skewed. In the 16 catchments located in the central and eastern parts, L. arcticus was recorded in $70 \%$ of all the lakes studied $(\mathrm{n}=191)$. The remaining 11 catchments located in western areas, are almost free of lakes with $L$. arcticus $(\mathrm{n}=47)$. The most striking difference between these two areas is the significantly higher level of snow deposition in the western areas. This delays the ice break-up, which results in lower water temperatures and a shorter growing season. The water of lakes in western areas $(\mathrm{N}=36)$ is also more dilute than those in the central and eastern areas $(\mathrm{N}=201)$, with mean calcium concentrations of $0.81 \pm 0.48$ and $1.62 \pm 1.12 \mathrm{mg} \mathrm{L}^{-1}$, respectively. In the lakes in the central and eastern areas hosting $L$. arcticus $(\mathrm{N}=95)$, the mean value was slightly higher $\left(1.67 \pm 1.14 \mathrm{mg} \mathrm{L}^{-1}\right)$. The combination of low water temperature, a short growing season and dilute water low in calcium may explain the near total absence of $L$. arcticus in the western part of Hardangervidda. All lakes contain brown trout Salmo trutta, and as $L$. arcticus is heavily sought for as food, the analyses of fish stomachs are the most reliable method of detecting the species. However, this prey-predator relationship may severely reduce the population of $L$. arcticus, and their presence may also be a function of the proximity of species refugia. This is evident in the context of fish predation, but also of water quality. Hence, in the central and eastern parts of the plateau, where L. arcticus is common, their occurrence increased significantly with lake size, being found in $54 \%$ of the lakes $<1.0 \mathrm{~km}^{2}$, as opposed to $97 \%$ in the bigger lakes. Furthermore, L. arcticus is most frequently found in lakes at altitudes between 1100 and $1299 \mathrm{~m}$ a.s.l. We conclude that environmental constraints limit the distribution of $L$. arcticus on Hardangervidda. The projected increase in temperature towards the end of this century may exterminate $L$. arcticus from the lower parts of Hardangervidda, especially in the most shallow lakes. Many of the lakes have water quality with $\mathrm{pH}<6.0$ and calcium concentration $<1.0 \mathrm{mg} \mathrm{L}^{-1}$. In such lakes $L$. arcticus is living on the edge of its survival, and the projected increase in precipitation may dilute the waters even further, pushing $L$. arcticus nearer to its extinction threshold.

doi: 10.5324/fn.v39i0.2687. Received: 2018-08-19. Accepted: 2019-06-05. Published online: 2019-07-11. ISSN: $1891-5396$ (electronic).

Keywords: Arctic tadpole shrimp, Salmo trutta, water quality requirements, thermal conditions, climate change

1. County Governor of Innlandet, Statens hus, Parkgata 36, NO-2317 Hamar, Norway

2. Norwegian Institute for Nature Research (NINA), PO Box 5685, Torgården, NO-7485 Trondheim

Corresponding author: Tore Qvenild

E-mail:fmhetq@fylkesmannen.no 


\section{INTRODUCTION}

The Arctic tadpole shrimp Lepidurus arcticus (Pallas, 1793) has a circumpolar distribution and occurs in both shallow moraine ponds and large lakes in subarctic areas (Hessen et al. 2004). In its central circumpolar area, $L$. arcticus is mainly found in ponds and fishless shallow lakes (Jeppesen et al. 2001; Lakka 2013). However, in Scandinavia it has been described as a boreo-alpine relict species that occurs at sea-level in the Arctic region, and at progressively greater altitudes towards the south (S. Sømme 1934; Økland \& Økland 2003). On the Norwegian mainland, it is a typically alpine species, mainly co-existing with fish ( $\mathrm{S}$. Sømme 1934; Aass 1969). In ponds and small shallow lakes in its southern outreach on the Scandinavian peninsula, which is often fishless, L. arcticus seems to be absent (S. Sømme 1934; Berg 1954; Blomkvist 1995; Klausen 2012).

The Hardangervidda mountain plateau in Southern Norway is the largest peneplain (eroded plain) in Europe (Anonymous 1974). This plateau marks the southernmost outreach of $L$. arcticus (S. Sømme 1934; Økland \& Økland 2003). The first to describe $L$. arcticus from this mountain plateau was HuitfeldtKaas (1911), who offered only a general description of the species as being an important food item for brown trout Salmo trutta Linnaeus, 1758. He used the name Apus glacialis (Braem, 1893) which together with Lepidurus glacialis (Packard, 1883) was commonly used in the early decades of the $20^{\text {th }}$ century (Økland \& Økland 2003). Other synonym names from this period were Monoculus arcticus (Pallas, 1793), Lepidurus spitzbergensis (Bernard, 1882), Apus productus var. glacialis (Braem, 1893) and Lepidurus ussuriensis (Sidorov, 1927). No Norwegian name was known for L. arcticus at that time. The Norwegian name "skjoldkreps" ("scale shrimp") was introduced by Dahl (1913). This is astonishing as L. arcticus is quite conspicuous due to its large size and archaic appearance, and it was well known by local fishermen. On the other hand, the other large crustacean, the amphipod Gammarus lacustris G.O. Sars, 1863 , had a variety of Norwegian local names such as "marflo, matflo, grunnåte, nettskjær, etc." (Dahl 1915).

The brown trout on Hardangervidda are of good size and quality and support a number of traditional fisheries (I. Sømme 1941). Their main crustacean food items are L. arcticus, $G$. lacustris and Eurycercus lamellatus A.F.M (Huitfeldt-Kaas 1911; Dahl 1917; I. Sømme 1941). Information regarding their occurrence has long been fragmentary and incomplete, and not until the beginnings of the 1970s did a rough distribution pattern appear that included almost all the records from the central and eastern parts of the plateau (Anonymous 1974).

The geology of Hardangervidda is highly variable and this is reflected in the water chemistry of the lakes, many of whose waters are low in $\mathrm{pH}$ and calcium (Skjelkvåle \& Henriksen 1998). Lepidurus arcticus is highly sensitive to acid water (Borgstrøm \& Hendrey 1976; Lakka 2013) becoming extinct in waters with a pH below 5.5 (Fjellheim \& Raddum 1990). The lowest ambient calcium concentration in lakes in which $L$. arcticus are reported is $1.52 \mathrm{mg} \mathrm{L}^{-1}$ (Borgstrøm et al. 1976). However, only three lakes were investigated and hence, the lower lethal threshold for calcium demand has yet to be established for L. arcticus. Rapid postmoult calcification of the exoskeleton is essential for all crustaceans, and lack of calcium may limit their success in localities with such water quality (Rukke 2002).

The water temperature is also vital to all aquatic crustaceans. The thermal conditions of lakes are not only a result of summer temperatures, but also related to snow accumulation during the winter. Snow deposition and spring temperature are the main drivers of ice break-up, and determine the water temperature regime (Kvambekk \& Melvold 2010). In catchments with heavy snowfall, the ice break-up may be delayed and thus lead to a thermal deficit that impedes the development of $L$. arcticus (Qvenild et al. 2018). Snow deposition on Hardangervidda is highly variable, with an almost fourfold increase in an east to west gradient (Qvenild et al. 2018).

In this study we hypothesised that the combination of low water temperature, short growing season and dilute water may impede ecdysis in L. arcticus. Furthermore, this particular crustacean is a large food item and is heavily fed upon by fish (Dahl 1920; Aass 1969; Borgstrøm et al. 1985; Jeppesen et al. 2001; Qvenild \& Rognerud 2018; Presthus Heggen et al. 2010). Species "living on the edge" may be exterminated by reinforced vectors such as fish predation (Aass 1969; Jeppesen et al. 2001; Presthus Heggen et al. 2010). Our key question is whether the distribution pattern of $L$. arcticus may be explained by these environmental variables. Furthermore, alpine ecosystems are expected to suffer severely from the effects of global warming (Lindholm et al. 2012, 2015) and climate change may be a threat to L. arcticus (Hessen et al. 2004; Lakka 2013; Qvenild et al. 2018; Väinölä et al. 2019). Detailed mapping of L. arcticus is therefore an essential aspect of identifying future range retractions.

\section{METHODS AND MATERIAL Study area}

The Hardangervidda landscape is characterized by barren, treeless moorland interrupted by numerous pools, lakes, rivers and streams. The plateau covers an area of about $9800 \mathrm{~km}^{2}$, of which the most remote areas account for about $8000 \mathrm{~km}^{2}$ (Anonymous 1974). In this area we included 27 catchments that cover $6569 \mathrm{~km}^{2}$ (Figure 1, Table 1). We have divided these catchments into two groups. Of the "11 western catchments", ten drain to the west, while of the "16 central and eastern catchments", nine drain to the east and seven to the west. The extent of these catchments was calculated using the NEVINA procedure (NVE Atlas, nve.no). Within this area, we have identified 930 named lakes covering $656 \mathrm{~km}^{2}$ with a median size $0.162 \mathrm{~km}^{2}$ (range $0.004-78.77 \mathrm{~km}^{2}$ ). These localities also included 27 reservoirs for hydropower production ranging in surface area from 0.48 to $78.77 \mathrm{~km}^{2}$ (Appendix 1). In addition, 
there are approximately 11,600 unnamed lakes and ponds covering $157 \mathrm{~km}^{2}$ (range $0.0006-0.7035 \mathrm{~km}^{2}$ ). Most of the 36 natural lakes with bathymetric maps on Hardangervidda have mean depths $<10 \mathrm{~m}$ (Appendix 1). Most of the lakes within the study area are situated at altitudes of $1100-1399 \mathrm{~m}$ a.s.l. (85\%), while $11 \%$ and $4 \%$ are located at lower and higher altitudes, respectively.

The western area is dominated by rocky terrain and expanses of bare rock with thin or no moraine-covered bedrock of Precambrian gneisses and granites and sparse or no vegetation. Some catchments in the central part comprise bedrock of Cambro-Silurian sedimentary origin. The bedrock in the eastern areas also covers gneisses and granites but has deeper layers of moraine. The water chemistry on Hardangervidda closely reflects the local bedrock geology (Skjelkvåle \& Henriksen 1998). Hence, the lakes are highly variable in water chemistry, ranging from lakes being practically free of electrolytes to lakes with high ionic strength. The content of total organic carbon (TOC) is very low, with $<2.0 \mathrm{mg} \mathrm{C} \mathrm{L}^{-1}$ in almost all lakes (Appendix 1).

Calcium concentration and $\mathrm{pH}$ are vital variables in the survival of $L$. arcticus. There are significant intermediary and seasonal variations in calcium concentration within a lake. The highest values of calcium are usually measured in the spring when the concentration may be more than twice the minimum values registered later in the season (Fjellheim et al. 2002, 2007, 2018). This variability is most prominent in small lakes and brooks. In bigger lakes the variation follows the same pattern but within a much more limited range. On the other hand, the lowest $\mathrm{pH}$ values are measured in the run-off period in the spring. However, we assume that the low ambient pH-levels encountered throughout the growth period in summer is most critical for $L$. arcticus as the run-off period is normally short and their resting eggs are very resistant to external stresses (Longhurst 1955; Blomquist 1995; Lakka 2013). Hence, we have used the minimum values of calcium and the concurrent $\mathrm{pH}$-value in summer-autumn when water quality series are available for assessing the occurrence of $L$. arcticus. Almost all

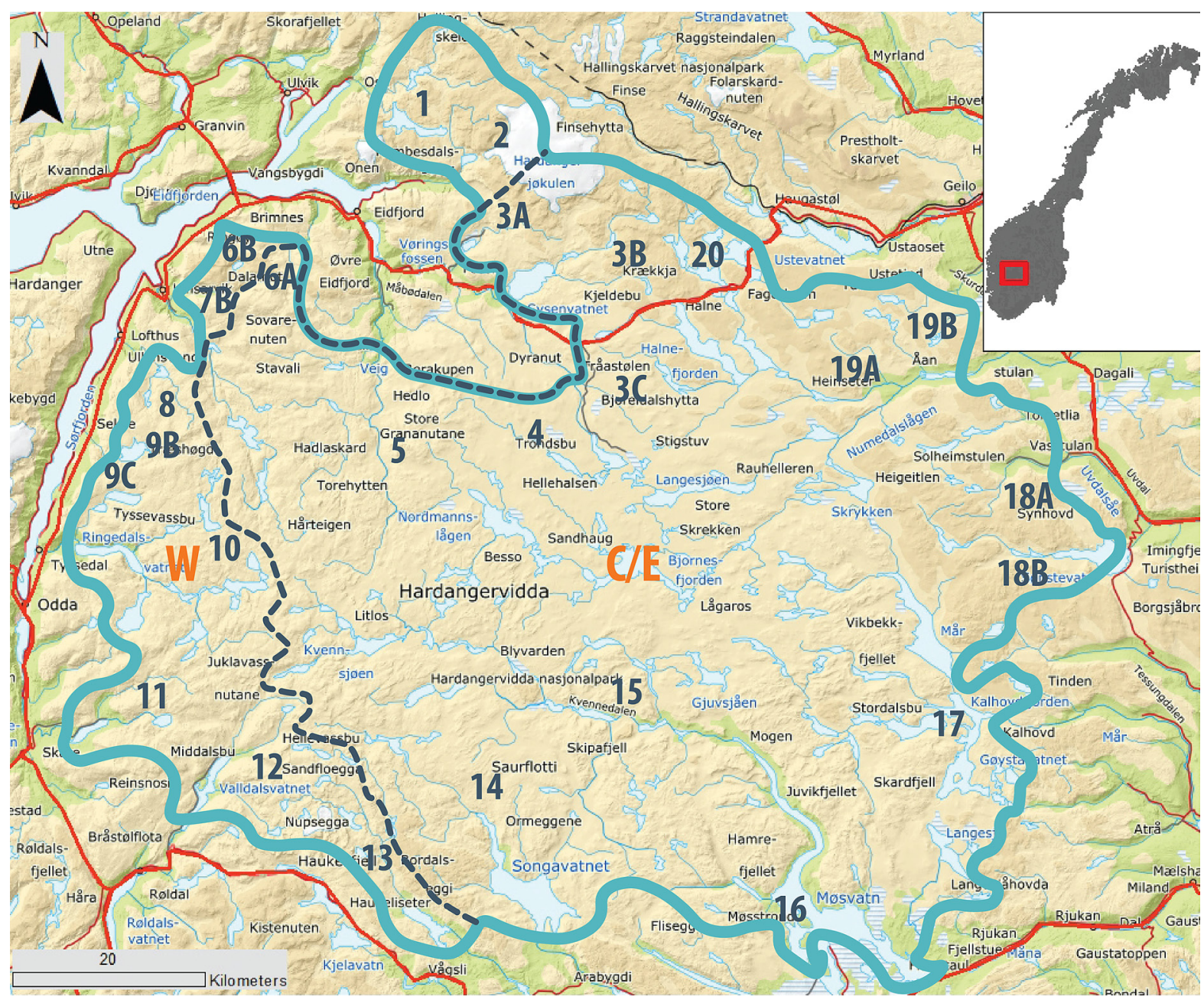

Figure I. Map of the Hardangervidda with the 27 catchments indicated. The boundary of the study area is marked by a blue line. Details of the catchments are shown in Table 1. The study area is divided into two groups with 11 western catchments (W) and 16 central and eastern catchments (C/E). These areas are divided by a dotted line. Norwegian Mapping Authority CC BY 4.0. 


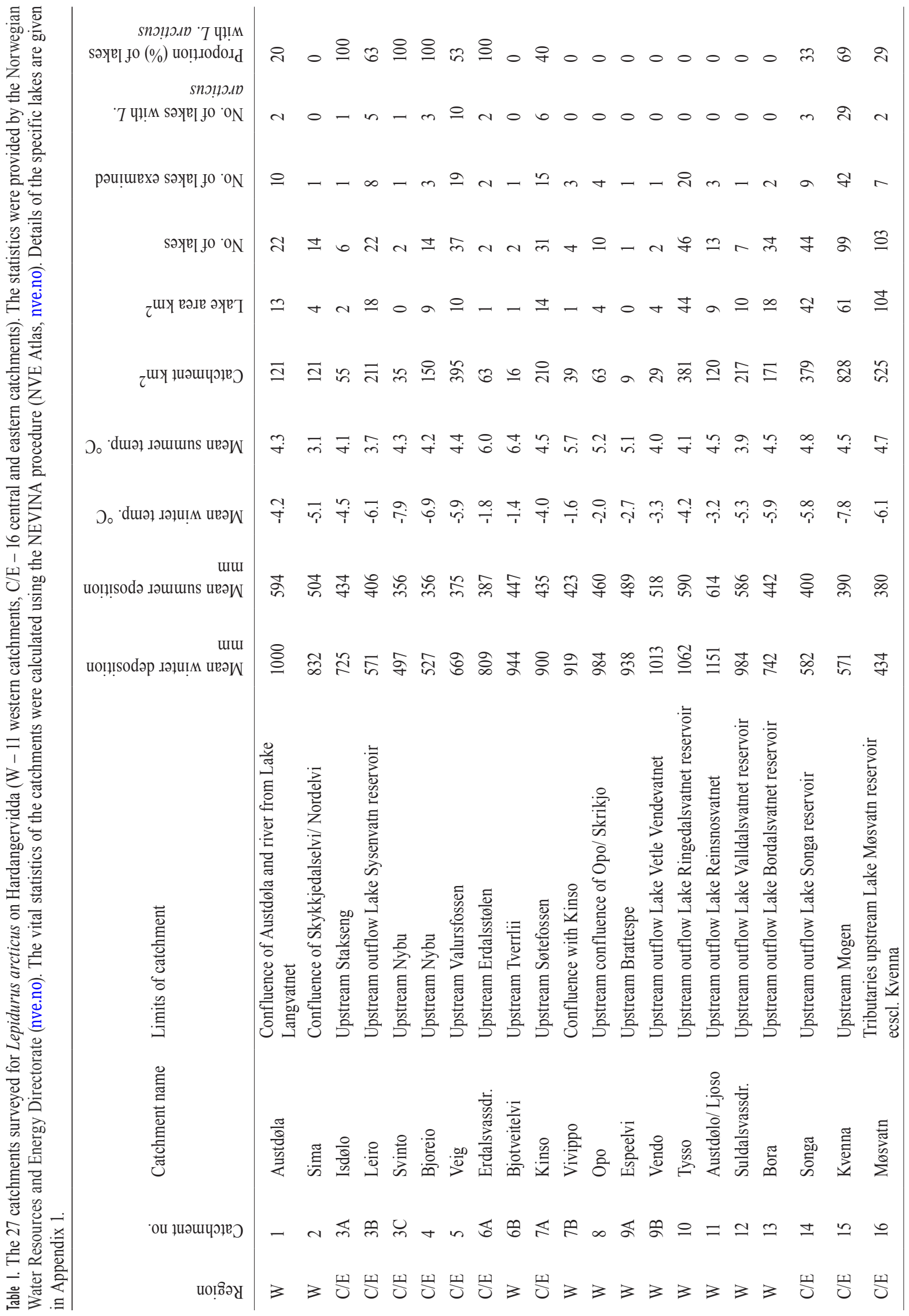




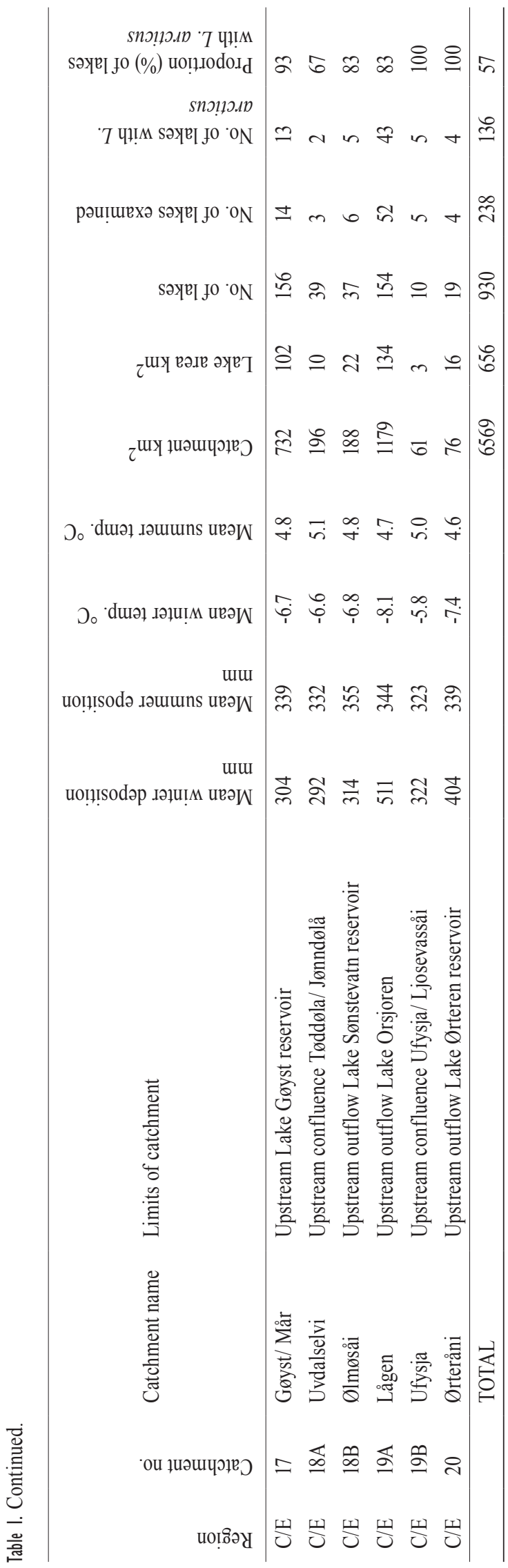

water chemistry data (97\%) are from the period July - October (Appendix 1). In many lakes, however, only single values of calcium are available. We have obtained water chemistry data (concurrent values of calcium concentration and $\mathrm{pH}$ ) from the literature for 237 lakes on Hardangervidda (Appendix 1).

The climatic conditions on Hardangervidda are highly variable (Qvenild et al. 2018). We used the NEVINA procedure to compute winter and summer deposition and winter and summer temperatures as mean values for the normal period 1961 - 1990 (NVE Atlas, nve.no). The winter deposition (October - April) differs substantially between the western and eastern parts of the plateau, being $1151 \mathrm{~mm}$ in Austdølo/Ljoso catchment and $292 \mathrm{~mm}$ in Uvdalselvi catchment, respectively (Table 1). Mean summer deposition values (May - September) are less divergent, being 614 and $332 \mathrm{~mm}$, respectively.

In most Hardangervidda lakes and rivers, brown trout is the only fish species present. Arctic char Salvelinus alpinus (Linnaeus, 1758) and European minnow Phoxinus phoxinus (Linnaeus, 1758) are coexisting with brown trout in some of the lakes (Appendix 1). Arctic char is found in 3.1\% ( N=29) of the 930 named lakes, mainly due to stockings in the $20^{\text {th }}$ century. In the Lågen catchment, they were stocked in Lake Breidvatnet, a headwater lake in the tributary Æanåi in 1910 (Dahl 1920), from where they spread downstream and to some neighbouring lakes in the following years. A dense population of Arctic char that emerged in Lake Breidvatnet affected the local crustacean community (Dahl 1920). More recently, Arctic char have also established themselves in the Leiro catchment (Rognerud et al. 2003). The European minnow has been introduced to $4.5 \%$ $(\mathrm{N}=42)$ of the 930 lakes since the 1970s. It was first observed in Lake Ørteren reservoir in 1973 (Anonymous 1974), from where it spread to many of the lakes in the north-eastern part of the plateau.

\section{Mapping of Lepidurus arcticus}

Data on the presence or absence of $L$. arcticus were screened from technical reports of varying standards and from some scientific papers (Appendix 1). Animals like L. arcticus may be difficult to detect using conventional benthic sampling equipment at low densities and/or patchy distribution (Fjellheim et al. 2007). Methods used in sampling L. arcticus on Hardangervidda include the Ekman bottom sampler (Dahl 1917; Amundsen 1976), Petersen sampler (Amundsen 1976), plankton sieves (Halvorsen 1973), artificial substrates (jute bags) and benthic littoral kick samples (Walseng et al. 1994; Walseng et al. 1996; Fjellheim et al. 2007). However, in most publications, the occurrence of $L$. arcticus is mainly based on brown trout stomach analyses.

Many reports contain only a note referring to a finding of L. arcticus. In more detailed investigations, the occurrence of different food items is normally given as volume $\%$ based on stomach analyses. In this study, the occurrence of $L$. arcticus is only noted as presence or absence of the species. In this context, we assume viable populations of $L$. arcticus in lakes 
where the species have been noted at least once. In lakes with negative findings of $L$. arcticus they may still occur as findings are highly sensitive to the method used (Amundsen 1976; Fjellheim et al. 2007), time of sampling (Aass 1969; Hesthagen 1979; Qvenild et al. 2018), thermal conditions (Aass 1969; Simonsen \& Valderhaug 1994; Borgstrøm 2016; Qvenild et al. 2018), and predation from dense fish populations (Dahl 1920; Aass 1969; Borgstrøm et al. 1985; Qvenild \& Rognerud 2018). This is emphasised by results from lakes repeatedly examined that produced both positive and negative findings (Hesthagen 1979; Qvenild \& Rognerud 2018). As most of the findings of $L$. arcticus are from stomach analyses, the records concern adult specimens. With hauls, different instar stages and nauplius larvae were also detected (Halvorsen 1973; Walseng et al. 1996).

\section{RESULTS}

\section{Distribution of lakes hosting Lepidurus arcticus}

Lepidurus arcticus was detected in 136 of 238 lakes (57\%) within the 27 catchments studied (Appendix 1, Table 1). Their pattern of distribution is highly skewed, with almost all the records coming from the 16 central and eastern catchments (Figure 2). In this area, 775 named lakes were identified. In the 181 natural lakes examined, L. arcticus was detected in $69 \%$ $(\mathrm{N}=124)$. Lepidurus arcticus occurred in all ten reservoirs in this area.

In the 11 western catchments, 155 named lakes were identified. Here, L. arcticus was searched for in 47 lakes, but recorded in only two (4.0\%), both in the Austdøla catchment in the north-western region (Lake Langvatnet and Lake Austdalsvatnet). Thus, in the remaining ten catchments in this region, L. arcticus has never been recorded.

\section{The significance of altitude and lake size}

We analysed the occurrence of $L$. arcticus in relation to altitude and lake size from natural lakes within the 16 catchments in the central and eastern parts of the plateau. The 124 lakes that contain $L$. arcticus in this area lie at altitudes between 832 and 1386 m a.s.l., most of them (77\%) between 1100 - 1299 m a.s.l.

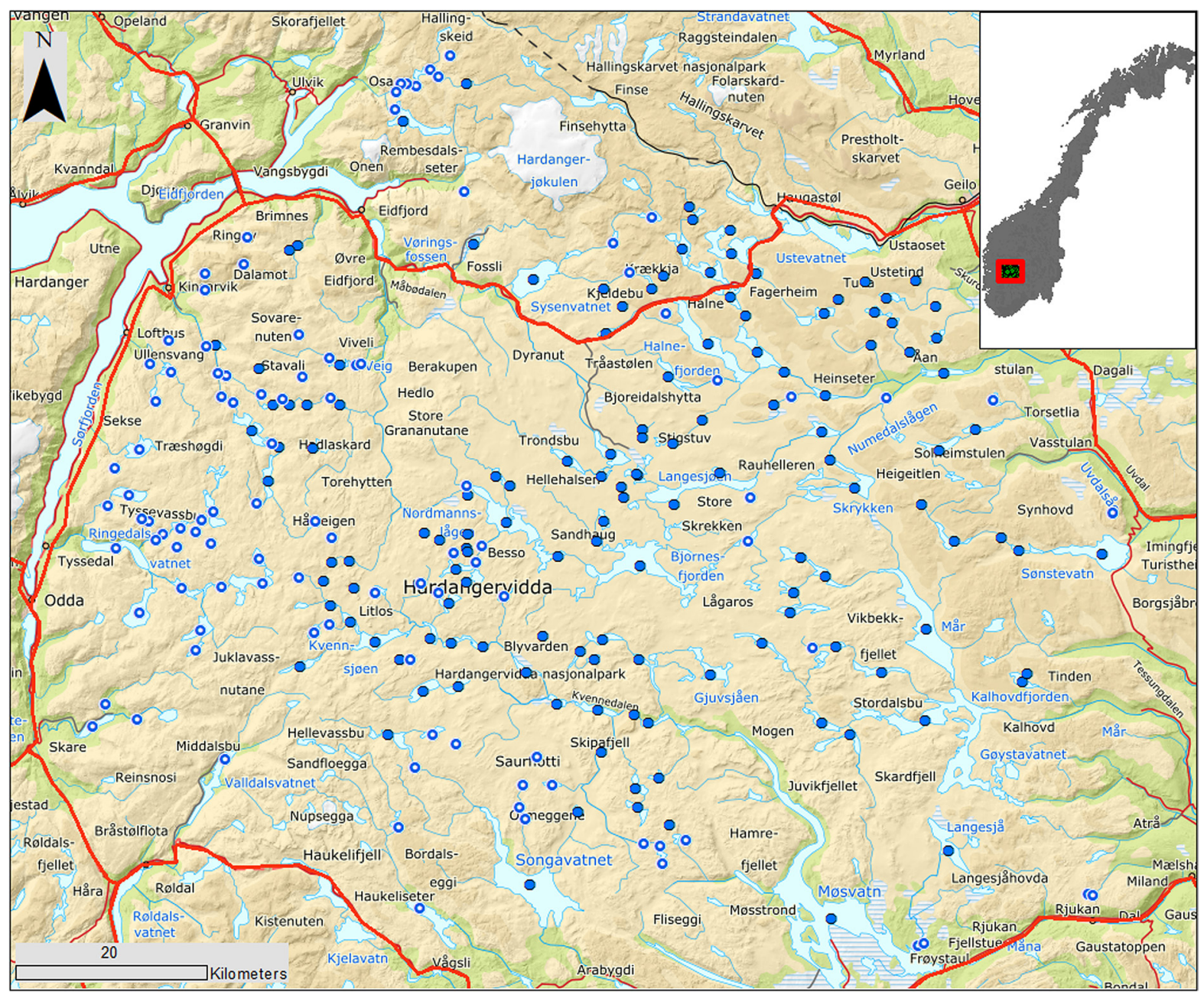

Figure 2. Lakes surveyed for the presence of Lepidurus arcticus are shown by dots, with positive findings shown by filled dots. Details of the localities are given in Appendix 1. Norwegian Mapping Authority CC BY 4.0. 
(Table 2). From an altitude of $900 \mathrm{~m}$ a.s.l., the proportion of lakes containing $L$. arcticus rose to its highest level at 1100 1199 m a.s.l., where $80 \%$ contained L. arcticus. In total, 50 and $72 \%$ of the lakes lower and higher than $1100 \mathrm{~m}$ a.s.l. hosted $L$. arcticus, respectively. Lake Kolsnutgryslane at $1386 \mathrm{~m}$ a.s.l., in the Kvenna catchment, is the highest known locality hosting $L$. arcticus on Hardangervidda. Of the 26 lakes at higher altitudes, only two lakes have been surveyed for $L$. arcticus, and both returned negative findings. Of the 19 lakes located at altitudes below $1000 \mathrm{~m}$ a.s.l., ten were surveyed, and five of them contained $L$. arcticus.

The 765 natural lakes in this area ranged in size from 0.004 to $18.38 \mathrm{~km}^{2}$, most of them covered an area $<1.0 \mathrm{~km}^{2}(90 \%)$. The probability of occurrence of $L$. arcticus increased significantly with lake size as shown by a logistic regression: $p$ (occurrence $)=$ $(1+\exp (1.380+2.026 \cdot \log \text { Area }))^{-1}$ (likelihood-ratio chi-square test $=31.12, \mathrm{p}<0.0001$ ) (Figure 3). Of the 181 lakes examined,

Table 2. Frequency (\%) of lakes with Lepidurus arcticus at different altitudes in the 16 central and eastern catchments on Hardangervidda.

\begin{tabular}{|c|c|c|c|c|}
\hline 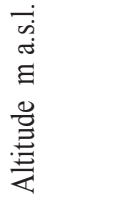 & 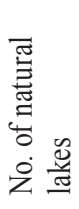 & 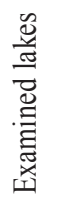 & 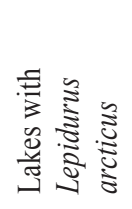 & 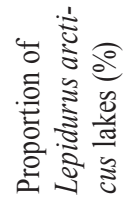 \\
\hline$<900$ & 4 & 4 & 3 & 75 \\
\hline 900-999 & 15 & 6 & 2 & 33 \\
\hline 1000-1099 & 59 & 18 & 9 & 50 \\
\hline $1100-1199$ & 264 & 66 & 53 & 80 \\
\hline $1200-1299$ & 270 & 57 & 42 & 74 \\
\hline $1300-1399$ & 141 & 30 & 15 & 50 \\
\hline \multirow[t]{2}{*}{$\geq 1400$} & 12 & 0 & 0 & 0 \\
\hline & 765 & 181 & 124 & 69 \\
\hline
\end{tabular}

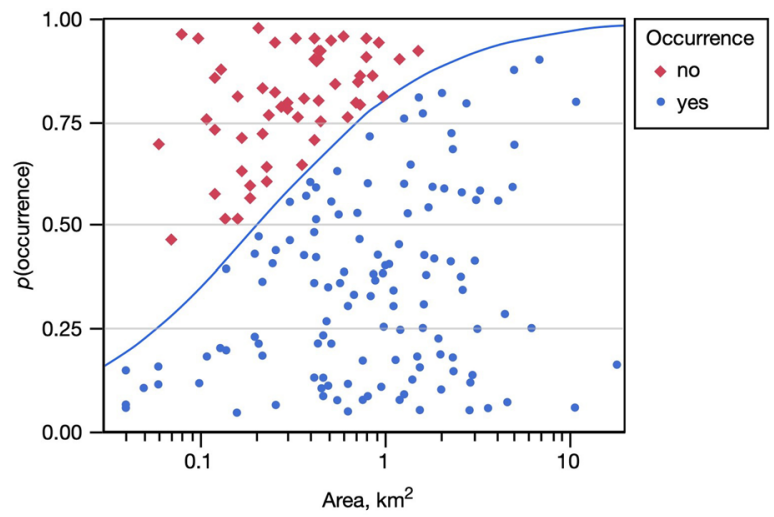

Figure 3. Logistic regression curve showing the probability of occurrence of Lepidurus arcticus as a function of lake surface area. Of the 181 lakes studied, Lepidurus arcticus was found in $97 \%$ of the 62 lakes $\geq 1.0 \mathrm{~km}^{2}$, while the species was found in only $54 \%$ of 119 lakes $<1.0 \mathrm{~km}^{2}$.
L. arcticus was found in $97 \%$ of the 62 lakes $\geq 1.0 \mathrm{~km}^{2}$, while the species was found in only $54 \%$ of the 119 lakes $<1.0 \mathrm{~km}^{2}$. The smallest lake with $L$. arcticus was Lake Nedre Vivevatn $\left(0.023 \mathrm{~km}^{2}\right)$.

\section{Occurrence of Lepidurus arcticus in relation to climate conditions and water chemistry}

The 11 catchments in the western part of the plateau with scarcely any $L$. arcticus had high winter depositions of snow, with a mean value of $961 \pm 109 \mathrm{~mm}$ (Table 1). Lakes in these catchments were consistently low in calcium, with a mean concentration of $0.81 \pm 0.48 \mathrm{mg} \mathrm{L}^{-1}$ (range $0.32-2.62 \mathrm{mg}$ $\mathrm{L}^{-1}, \mathrm{~N}=36$ ) (Appendix 1). Calcium concentrations in the two localities with $L$. arcticus in this area, lakes Langvatnet and Austdalsvatnet, were 0.32 and $1.20 \mathrm{mg} \mathrm{L}^{-1}$, respectively. Of the 36 localities, $72 \%$ had calcium concentrations $<1.0 \mathrm{mg} \mathrm{L}^{-1}$. The concurrent $\mathrm{pH}$ in these lakes ranged from 5.35 to 7.00 , with $19 \%$ lying below 6.0. The TOC values are extremely low, with all values $\leq 0.6 \mathrm{mg} \mathrm{C} \mathrm{L}^{-1}$.

On the other hand, in the 16 catchments in central and eastern areas in which $L$. arcticus is common, the mean winter deposition is $527 \pm 183 \mathrm{~mm}$ (Table 1). Concurrent values of calcium concentration and $\mathrm{pH}$ were available from 201 lakes (Appendix 1), with a mean calcium concentration of $1.61 \pm 1.12$ $\mathrm{mg} \mathrm{L}^{-1}$. The minimum and maximum calcium values for the lakes in this area were measured in Lake Svartavasstjørni (Lågen catchment) and Lake Nøkkatjørni (Bjoreio catchment), with 0.28 and $5.73 \mathrm{mg} \mathrm{L}^{-1}$, respectively. In this area, $37 \%$ of the lakes had a calcium concentration $<1.0 \mathrm{mg} \mathrm{L}^{-1}$. The concurrent $\mathrm{pH}$ varied from 5.19 to 7.28 , with $10 \%<6.0$. In this area, $L$. arcticus is recorded in 95 lakes in which the mean calcium concentration was $1.67 \pm 1.14 \mathrm{mg} \mathrm{L}^{-1}$ (range $0.28-5.54 \mathrm{mg} \mathrm{L}^{-1}$ ). The concurrent $\mathrm{pH}$ values ranged from 5.49 to 7.26 also with $11 \%$ of the values $<6.0$. Also in this area, the TOC values are low, as $85 \%(\mathrm{~N}=52)$ of the localities were below $2.0 \mathrm{mg} \mathrm{C} \mathrm{L}^{-1}$.

Winter deposition and calcium concentration were significantly different between the western and the central/ eastern areas (likelihood-ratio chi-square test $=120.91$ $(p<0.0001)$ and $20.61(p<0.0001))$, respectively (Figure 4$)$. At calcium concentrations $<1.0 \mathrm{mg} \mathrm{L}^{-1}$, no positive findings of $L$. arcticus were found in areas with snow deposits $>700 \mathrm{~mm}$.

Both winter deposition (Wd) and calcium concentration (Ca) could be used to characterise the western and central/ eastern areas respectively. The probability of being categorised as a lake in the central/eastern area could be modelled by a logistic regression: $\mathrm{p}=1-(1+\exp (15.158+4.278 \cdot \log \mathrm{Ca}-$ $0.019 \cdot \mathrm{Wd}))^{-1}\left(\right.$ likelihood-ratio $\chi^{2}$ test $=169.7, \mathrm{p}<0.0001$ ). 


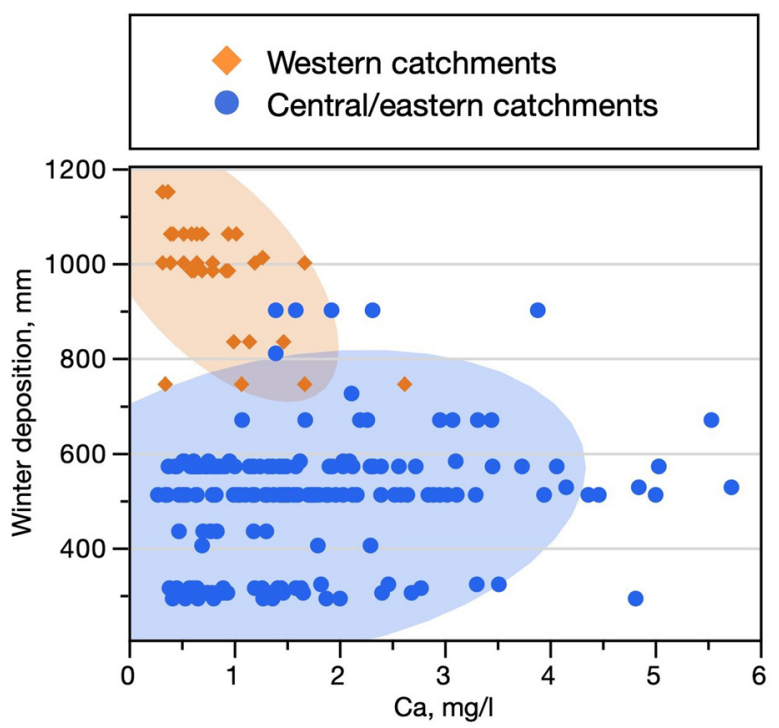

Figure 4. Scatter plot of calcium concentration $\left(\mathrm{mg} \mathrm{L}^{-1}\right)$ and winter deposition $(\mathrm{mm})$ for the lakes in the two catchment areas. Bivariate $90 \%$ confidence ellipses are shown for each of the two areas.

\section{DISCUSSION}

In 1910, the first six localities with L. arcticus in the northeastern part of Hardangervidda were documented (Dahl 1917), and by 1940, only 20 lakes with L. arcticus had been identified (Dahl 1917; S. Sømme 1934). This came to 50\% of all Norwegian lakes that were known to host L. arcticus at that time. In the 1970s, enough investigations had been conducted to trace a rough distribution pattern on Hardangervidda (Anonymous 1974). Lepidurus arcticus is well established in the southern mountain range in Norway in the alpine zone (zone above the tree line) and to some extent in the subalpine zone (mainly the birch zone), indicating that temperature preferences limit its distribution. However, in the western part of Hardangervidda it must be additive vectors. This study focuses on the environmental conditions, in order to elucidate why $L$. arcticus is missing in this region.

\section{The significance of the sampling method}

In many lakes, different kind of bottom samplers are used simultaneously with fish sampling (Dahl 1917; Amundsen 1976; Fjellheim et al. 2007). In a test-fishing programme that covered 15 lakes hosting L. arcticus, bottom samplers (Ekman or/and Petersen) were used simultaneously with test fishing (Amundsen 1976). In only one lake (7\%), L. arcticus was detected by the bottom samplers, compared with 12 lakes $(80 \%)$ from which stomachs were analysed. In a monitoring programme with benthic littoral kick sampling in 18 lakes hosting L. arcticus in 1978, repeated in 1994, L. arcticus was detected in only one lake in each of the sampling periods (Walseng et al. 1994, 1996). In the 1994 investigation, brown trout were also sampled with multimesh gillnets in six lakes, five of which provided
L. arcticus. In a similar study in two lakes, artificial substrate (jute bags) and benthic littoral kick sampling were used in addition to stomach sampling (Fjellheim et al. 2007). In these lakes, where L. arcticus appeared in low numbers, only fish stomach analyses had positive findings. Stomach analyses thus proved to be far the most effective method to detect the presence of L. arcticus, especially when L. arcticus appears in low number and/ or has a patchy distribution.

Even though adult L. arcticus is a big food item, it is not necessarily easy to catch for the brown trout, especially not to the small sizes. It was a significant positive correlation between the frequency (\%) of L. arcticus in the fish stomachs and fish size (Qvenild et al. 2018). In fishery investigations, multimesh gillnets are frequently used. In clear water mountain lakes, small brown trout tends to pose the dominant part of the catch in such gears. If so, the probability to detect L. arcticus may be lower.

In our material, 423 investigations can be properly dated, 102 of which delivered negative findings in lakes known to host $L$. arcticus. This may be due to timing (early sampling), methods used, low density and/ or patchy distribution of $L$. arcticus. As $44 \%(\mathrm{~N}=102)$ of these studies took place in June - July, timing seems to be crucial. Most fish investigations in high mountain lakes where $L$. arcticus is expected as a food item take this into account. Of the 423 investigations, $80 \%$ took place in August to October.

Although L. arcticus may thrive at low temperatures, a minimum thermal input is needed for their growth into adult stages (Qvenild et al. 2018). This is emphasized in cold summers where L. arcticus has a delayed appearance as brown trout food (S. Sømme 1934; Aass 1969; Pedersen \& Scobie 1990; Simonsen \& Valderhaug 1994; Borgstrøm 2016). In cold summers such as those of 2012 and 2015 they may not be seen until September, if at all (Borgstrøm 2016; Qvenild et al. 2018). In an extensive study covering 236 fishing events from five lakes on Hardangervidda in 2003 - 2016, the fishing events with positive findings covered a period from 27 July (in 2009) to 2 October (in 2006). In the surveyed literature (cf. references in Appendix 1), $10 \%$ of those with positive findings were from July. Only in one investigation was L. arcticus detected earlier than 18 July (11 July in Lake Isdalsvatnet; Lehman \& Wiers 2004). This confirms existing experience that $L$. arcticus basically contributes to the brown trout diet in August - September on Hardangervidda (Dahl 1917; I. Sømme 1941).

In the 16 central and eastern catchments, L. arcticus was recorded in $70 \%$ of the 191 lakes examined (including the ten reservoirs). Lepidurus arcticus was recorded in 55\% of the 124 lakes sampled once or twice. With more than two repeat samplings, almost all gave positive records (99\%). This was also emphasized in an extensive study in Lake Sandvatn in Kvenna catchment in 2003 - 2016 (Qvenild \& Rognerud 2018), where, L. arcticus contributed significantly as brown trout food in August in most years. However, in some years they were scarcely ever observed. This was partly due to cold summers 
$(2012,2015)$ and partly to predation pressure from brown trout $(2006,2007)$. Thus, repeated sampling is essential in detecting L. arcticus.

Fish predation may serious reduce $L$. arcticus populations. On Hardangervidda this has been shown for brown trout (Qvenild \& Rognerud 2018), Arctic char (Dahl 1920; Aass 1969) and European minnow (Rognerud et al. 2003). When one or more of these species are present, $L$. arcticus may be difficult to detect.

\section{The distribution pattern and potential for new observations of Lepidurus arcticus}

Hardangervidda marks the southernmost distribution limit of $L$. arcticus, although a few localities in the neighbouring mountain area further south are known (S. Sømme 1934; Borgstrøm et al. 1976; Økland \& Økland 2003; Artsdatabanken.no). This study revealed 136 lakes hosting L. arcticus (cf. Table 1). Almost all the lakes are located in the central and eastern part of the mountain plateau. Our study has thus confirmed the pattern of distribution seen in the beginning of the 1970s (Anonymous 1974). However, it is now based on far more localities.

In the 16 catchments at the central and eastern part of the plateau where $L$. arcticus is common, $25 \%$ of the named lakes $(\mathrm{N}=775)$ have so far been properly surveyed. This particular crustacean can be difficult to catch, and investigations that include more than two repeat samplings may be needed to be certain of detecting it. Of the 191 lakes, only $35 \%$ have been examined more than twice and the potential for new findings of $L$. arcticus is obvious. Hence, the estimate that at least 136 localities host $L$. arcticus in this area should easily be increased by more targeted surveys.

The distribution of $L$. arcticus throughout the Norwegian mountain range, which decreases to the north, is mainly explained by their temperature preferences (S. Sømme 1934; Aass 1969; Økland \& Økland 2003). The general drop in air temperature, which falls by about $0.6^{\circ} \mathrm{C}$ per $100 \mathrm{~m}$ altitude correlates with a corresponding drop in water temperature (Kvambekk \& Melvold 2010; Lindholm et al. 2015; Qvenild et al. 2018). Hence, a thermal deficit in the input needed to complete its reproductive cycle may limit the species at high altitudes (cf. Aass 1969: Qvenild et al. 2018). This may be reflected in the maximum frequency of $L$. arcticus found in lakes at altitudes of $1100-1299 \mathrm{~m}$ a.s.l (cf. Table 2). On Hardangervidda the highest lake hosting L. arcticus is Lake Kolsnutgryslane at $1386 \mathrm{~m}$ a.s.l. However, they may exist at higher altitudes as the species has been recorded up to $1518 \mathrm{~m}$ a.s.l. nationwide (Økland \& Økland 2003). On Hardangervidda only 26 lakes (3.4\%) are sited at higher altitudes than $1386 \mathrm{~m}$ a.s.l. and only two of them have so far been examined.

Lepidurus arcticus normally reach their maximum abundance in the alpine zone in Southern Norway (S. Sømme 1934; Aass 1969; Økland \& Økland 2003). However, their distribution may extend into the subalpine zone, especially in lakes regulated for hydropower production (Dahl 1932; Aass
1969). The resting eggs of $L$. arcticus tolerate both freezing and drying (Dahl 1932; Longhurst 1955; Aass 1969; Blomkvist 1995). Thus, they are well adapted to the unstable conditions in the littoral zone in reservoirs with variable water levels. However, in this context, temperature conditions seem to be crucial, as was revealed in Lake Pålsbufjorden at 749 m.a.s.l. lower in the Lågen catchment (Dahl 1932). The regulation regime turned the lake into a colder habitat suitable for the development of L. arcticus (Aass 1969).

The water level amplitude in hydropower reservoirs does not seem to be decisive (Aass 1969). All the ten reservoirs in the central and eastern parts of Hardangervidda still host $L$. arcticus despite water amplitudes up to $66 \mathrm{~m}$ (Lake Sysenvatn). In the western catchments, no records of $L$. arcticus after impoundment are known. Consequently, there must be other factors that limit their occurrence in reservoirs in this part of the plateau.

The presence of a species is a function of the proximity of suitable refugia. In this study, the occurrence of L. arcticus increased significantly with lake size, which demonstrates that this is a factor of great significance, as access to refugia in larger and deeper lakes tends to be better. In this context, this seems to be a crucial factor, relative to both water quality and fish predation (Fjellheim et al. 2007; Qvenild \& Rognerud 2018).

In addition to the 930 named lakes on Hardangervidda, there are large numbers of unnamed lakes and ponds. In the high Arctic, L. arcticus is common in such localities although they may freeze solid throughout the winter (Lakka 2013). Lepidurus arcticus have also been recorded in some small lakes and ponds on the Scandinavian peninsula (Berg 1954; Hesthagen 1979; Blomkvist 1995; Walseng et al. 1996). Even in such localities, L. arcticus seems to be an exception (S. Sømme 1934; Halvorsen 1973; Blomkvist 1995; Klausen 2012; Walseng et al. 1996). In most small lakes and ponds, the environmental conditions may be too variable and lack the necessary refugia to provide survival conditions for $L$. arcticus. Both temperature and acid water may have detrimental impacts in such localities (Olofsson 1918 cited in Blomkvist 1995; Fjellheim et al. 2001; Lakka 2013). Another branchiopod, Branchinecta palludosa O.F.Müller, 1758, has been extinct in many ponds on its southernmost border in the Dovrefjell mountain area since the 1970s, which was related to elevated summer temperatures (Lindholm et al. 2012, 2015). Lepidurus arcticus may also be susceptible to rises in temperatures in the upper part of their thermal range (Arnold 1966; Klausen 2012; Lakka 2013).

\section{Environmental constraints on the distribution of Lepidurus arcticus}

On Hardangervidda, the western area is extremely barren with only a thin layer of moraine or glacio-fluvial deposits on Precambrian bedrock, almost without vegetation and with a bedrock of granitic and dioritic gneisses, giving dilute water low in calcium $\left(0.81 \pm 0.48 \mathrm{mg} \mathrm{L}^{-1}\right)$. The catchments in the 
central and eastern areas where $L$. arcticus commonly occurs, has a thicker moraine cover with more vegetation, and the water quality is much better with respect to calcium $(1.61 \pm 1.12 \mathrm{mg}$ $\mathrm{L}^{-1}$ ). In the western and central/ eastern part, $72 \%$ and $38 \%$ of the lakes have calcium concentrations $<1.0 \mathrm{mg} \mathrm{L}^{-1}$, respectively.

The lower lethal threshold for calcium demand has yet to be established for L. arcticus. The species is also highly sensitive to acid water, becoming extinct in waters with pH below 5.5 (Borgstrøm \& Hendrey 1976; Fjellheim \& Raddum 1990; Lakka 2013). Rapid postmoult calcification of the exoskeleton is essential to all crustaceans, and low calcium concentrations may impede ecdysis (Rukke 2002). This effect may be reinforced by low $\mathrm{pH}$ levels, which often interfere with low calcium concentrations. Almost all the 29 lakes with $\mathrm{pH}<6.0$, ten of which hosted $L$. arcticus (cf. Appendix 1) had calcium concentrations $<1.0 \mathrm{mg} \mathrm{L}^{-1}$. In these lakes, $L$. arcticus may cope with such extremes and must be regarded as "living on the edge" of survival. At such critical levels, access to proximity refugia is assumed to be crucial. In Lake Svartevatnet in Lågen catchment, L. arcticus was not recorded until the water quality was improved by a liming programme that started in 1994 (Fjellheim et al. 2001). This was assumed not to be an effect of the stocking of $L$. arcticus, but rather of access to refugia within the lake with better water quality. Hence, the lower thresholds to $\mathrm{pH}$ and calcium should exceed the measured level in Lake Svartevatnet in 1993, i.e. prior to liming. In that year, the summer calcium concentration and $\mathrm{pH}$ were $0.35 \mathrm{mg} \mathrm{L}^{-1}$ and 5.69 , respectively. This indicates that ambient calcium concentration levels $\sim 0.5 \mathrm{mg} \mathrm{L}^{-1}$ is near to the lower lethal threshold for $L$. arcticus.

This study has clearly shown that $L$. arcticus can thrive in waters lower in calcium than $<1.0 \mathrm{mg} \mathrm{L}^{-1}$ and also with $\mathrm{pH}<6.0$. Even though the lakes in the two areas have quite different levels of calcium, many of them with positive findings of $L$. arcticus in the central/ eastern area lie within the lower range of the scale, with 35 lakes having calcium concentrations $<1.0 \mathrm{mg} \mathrm{L}^{-1}$, and seven of them $<0.5 \mathrm{mg} \mathrm{L}^{-1}$. Thus, the calcium concentration in most of the lakes in the western area should not be critical to L. arcticus survival and in this part of Hardangervidda, additional vectors determine their absence or presence.

There is a steep gradient in snow deposition from west to east, with $1151 \mathrm{~mm}$ in the Austdøla/Ljoso catchment in the west, compared to $292 \mathrm{~mm}$ in the Uvdalselvi catchment in the east (cf. Table 1). All the western catchments have snow deposits $>700 \mathrm{~mm}$. Heavy snow deposits seriously affect the thermal conditions in the lakes (Borgstrøm 2016; Qvenild et al. 2018). The large amounts of snow deposited in western areas imply that the ice break-up usually takes place much later than in eastern areas (Borgstrøm 2016; Qvenild et al. 2018). Hatching of $L$. arcticus normally coincides with snow melt and ice break-up (Halvorsen 1973; Simonsen \& Valderhaug 1994; Fjellheim et al. 2007; Borgstrøm 2016). Though low temperature is not a problem to an arctic species like $L$. arcticus, a minimum thermal input is needed for development into adults (Qvenild et al. 2018). High winter deposition, late ice break-up and low water temperatures in a short growing season may seriously impede the growth and development of L. arcticus. Evidence for this was documented for a number of individual years on Hardangervidda (Pedersen \& Scobie 1990: Simonsen \& Valderhaug 1994; Borgstrøm 2016; Qvenild et al. 2018). Thus, the combination of low thermal input and dilute waters in this area may result in excessively hostile conditions to $L$. arcticus. When calcium concentrations are $<1.0 \mathrm{mg} \mathrm{L}^{-1}$, L. arcticus was not found in areas with snow deposits $>700$ mm. (cf. Figure 4). However, L. arcticus may maintain viable populations even in some lakes in areas with snow deposition $>700 \mathrm{~mm}$. Lake Busetevatn in the Erdalsvassdraget catchment and lakes in the Kinso catchment host $L$. arcticus despite winter depositions of $\sim 900 \mathrm{~mm}$. However, these lakes have relatively high calcium concentrations $\left(>1.4 \mathrm{mg} \mathrm{L}^{-1}\right)$. Hence, L. arcticus is able to complete its life cycle even with snow deposits $>700$ $\mathrm{mm}$, if calcium levels are sufficiently high.

\section{Climate change - what will be the consequences for Lepidurus arcticus?}

For the Norwegian mainland as a whole, there has been a general increase in precipitation since the 1980s (HanssenBauer et al. 2017). This pattern has also been observed on Hardangervidda, where the annual winter deposition has increased, including an increase in the number of snow-rich winters with a decrease in the difference from west to east (Qvenild et al. 2018). In addition to later ice break-up and colder waters, elevated precipitation levels will result in higher run-off and more dilute waters (Presthus Heggen et al. 2010.

A similar significant increase in summer air temperatures since the 1980s has also been documented on Hardangervidda (Qvenild et al. 2018), and a further increase is projected toward the end of the century. As water temperature is closely linked to air temperature this will also affect the aquatic biota (Kvambekk \& Melvold 2010; Lindholm et al. 2015; Qvenild et al. 2018). In shallow lakes and ponds, the water temperature may exceed the upper tolerance limit of L. arcticus, which is estimated to be $19-20{ }^{\circ} \mathrm{C}$ (Arnold 1966; Klausen 2012; Lakka 2013), although it may be higher for short duration exposures. In deeper lakes, the water temperature seldom passes these tolerance limits for more than a few days, and only in the epilimnion (Qvenild et al. 2018). Hence, lake size would appear to be important for $L$. arcticus survival in a future warmer climate.

The ecological sensitivity is high in mountain areas, where many species are living at the thresholds of their tolerance and close to their geographical limits. Hence, protracted warm periods may be problematic for a cold-adapted species like $L$. arcticus at the southernmost outreach of its distribution range. Even though $L$. arcticus may tolerate high temperatures for some time, the accumulated thermal input may exceed the upper thermal threshold and result in mismatches between environmental conditions and life-cycle events. This may force range retractions of $L$. arcticus from the lower part of their 
distribution area, as has already been experienced by another crustacean species, B. paludosa (Lindholm et al. 2012, 2015). From a conservation point of view, detailed mapping of the present distribution of $L$. arcticus on Hardangervidda should be highly rewarding.

\section{ACKNOWLEDGEMENTS}

The authors are grateful to Eirik Fjeld for valuable help with the statistics, and Roar Kiær for drawing the maps.

\section{REFERENCES}

Aass P. 1969. Crustacea, especially Lepidurus arcticus Pallas, as brown trout food in Norwegian mountain reservoirs. Institute of Freshwater Research, Drottningholm. Report No 49, 1969: 183-201.

Amundsen T. 1976. Fiskeribiologiske undersøkelser for Dagalivassdraget 1974-75. Fiskerikonsulenten for Øst-Norge. Rapport Na IV-3.2. 285 pp. (In Norwegian).

Anonymous. 1974. Hardangervidda. Natur - Kulturhistorie Samfunnsliv. Miljøverndepartementet (NOU: Norges offentlige utredninger). 1974:30 B. 352 pp. (In Norwegian).

Arnold GP. 1966. Observations on Lepidurus arcticus (Pallas) (Crustacea, Notostraca) in east Greenland. Annals and Magazine of Natural History 9: 599-617.

Berg M. 1954. New localities of Lepidurus arcticus Pallas in North-Norway. Astarte. No 9 (1954): 1-3.

Blomkvist D. 1995. Bladfotingar som forsuringsindikatorer $\mathrm{i}$ fjällen. Länsstyrelsen i Norrbottens län. Rapport nr. 3-1995. 30 pp. (In Swedish).

Borgstrøm R. 2016. Auren på Hardangervidda er sterkt påverka av klimatilhøve. Naturen nr. 4-2016: 147-155. (In Norwegian). doi: 10.18261/issn.1504-3118-2016-04-02

Borgstrøm R, Brittain J, Lillehammer A. 1976. Evertebrater og surt vann, oversikt over innsamlingslokaliteter. SNSF-prosjektet, IR 21/76. 33 pp. (In Norwegian with an English summary).

Borgstrøm R, Hendrey GR. 1976. pH tolerance of the first larval stages of Lepidurus arcticus (Pallas) and adult Gammarus lacustris G.O.Sars. SNSF-prosjektet, IR 22/76. 37 pp.

Borgstrøm R, Garnås E, Saltveit SJ. 1985. Interactions between brown trout, Salmo trutta L., and minnow, Phoxinus phoxinus (L.) for their common prey, Lepidurus arcticus (Pallas). Verh. Int. Ver. Limnol. 22: 2548-2552.

Dahl K. 1913. Laks og ørret. Fiskeri og kultur. Håndbok for fiskere, jordbrukere og skogsfolk. Nordisk forlag (Kristiania). 184 pp. (In Norwegian).

Dahl K. 1915. En studie over grundaatens eller matfloens (Gammarus pulex) biologi og utbredelse i Norge. Særtrykk av Norges Jæger- og Fiskerforenings Tidsskrift 1915. 32 pp. (In Norwegian).

Dahl K. 1917. Ørret og ørretvann. Studier og forsøk (new edition in 1943). J.W.Cappelens forlag. 182 pp. (In Norwegian).

Dahl K. 1920. Studier over røje i ørretvand. Norges Jæger- og Fiskerforenings Tidsskrift 1920: 233-248. (In Norwegian).

Dahl K. 1932. Influence of water storage of food conditions on trout in Lake Paalsbufjord. Skrifter utgitt av Det Norske Videnskaps-Akademi i Oslo. I. Mat.-Naturv. Klasse. 1931. No. 4. $53 \mathrm{pp}$.

Fjellheim A, Raddum GG. 1990. Acid precipitation: biological monitoring of streams and lakes. The Science of the Total Environment, 96: 57-66.

Fjellheim A, Tysse A, Bjerknes W. 2001. Reappearance of highly acid sensitive invertebrates after liming of an alpine lake ecosystem. Water, Air and Soil Pollution 130: 1391-1396.

Fjellheim A, Tysse Å, Bjerknes V, Wright RF. 2002. Finprikkauren på Hardangervidda. DN-utredning 2002-1. 58 pp. (In Norwegian).

Fjellheim A, Tysse A, Bjerknes W. 2007. Fish Stomachs as a Biomonitoring Tool in Studies of Invertebrate Recovery. Water, Air and Soil Pollution 7: 293-300. doi: 10.1007/s11267-0069074-X

Fjellheim A, Tysse Å, Gåsdal O, Stakseng H. 2018. Finprikkauren på Hardangervidda. UNI Research Miljø - LFI, Univ. i Bergen. Årsrapport 2017. 14 pp. (In Norwegian).

Hanssen-Bauer I, Førland EJ, Haddeland I, Hisdal H, Lawrence D, Mayer S, Nesje A, Nilsen JEØ, Sandven S, Sandø AB, Sorteberg A, Ådlandsvik B. 2017. Climate in Norway 2100 - a knowledge base for climate adaption. The Norwegian Center for Climate Services (NCCS). Report no. 1/2017. 45 pp.

Halvorsen G. 1973. Crustacea from the High Mountain Area Hardangervidda. Reports from the High Mountain Ecology Research Station, Finse, Norway. University of Oslo. 1973:2. $17 \mathrm{pp}$.

Hessen D, Rueness EK, Stabell M. 2004. Circumpolar analysis of morphological and genetic diversity in the Notostracan Lepidurus arcticus. Hydrobiologia 519: 73-84.

Hesthagen T. 1979. Utbredelse av skjoldkreps Lepidurus arcticus i Lom kommune, Oppland. Fauna 33: 30-33. (In Norwegian).

Huitfeldt-Kaas H. 1911. Indberetning om Fiskeriforholdene paa Hardangervidden. I: Indstilling fra Fjeldbeitekomiteen om Harangviddens Utnyttelse. Landbruksdepartementet. (Centraltrykkeriet, Kristiania). 106 pp. (In Norwegian).

Jeppesen E, Christoffersen K, Landkildehus F, Lauridsen T, Amsinck SL, Riget F, Søndergaard M. 2001. Fish and crustaceans in northeast Greenland lakes with special emphasis on interactions between Arctic char (Salvelinus alpinus), Lepidurus arcticus and benthic chydorids. Hydrobiologia 442: 329-337.

Klausen TR. 2012. Population regulation in the tadpole shrimp Lepidurus arcticus. MSc-thesis, Norwegian University of Science and Technology, Department of Biology. 25 pp.

Kvambekk AS, Melvold K. 2010. Long-term trends in water temperature and ice cover in the subalpine lake, Øvre Heimdalsvatn, and nearby lakes and rivers. Hydrobiologia (2010) 642: 47-60. doi: 10.1007/s10750-010-0158-2

Lakka H-K. 2013.The ecology of a freshwater crustacean: Lepidurus arcticus (Branchiopoda, Notostraca) in a high Arctic region. The University Centre in Svalbard, Department of High Arctic Biology. MS Thesis. 151 pp.

Lehmann GB, Wiers T. 2004. Fiskeressursprosjektet i Hordaland: Fiskeundersøkelser i regulerte innsjøer og vassdrag i Hordaland, juli 2002 - april 2003. Fylkesmannen i Hordaland, miljøvernavdelingen. Rapport nr. 1-2004. 79 pp. (In Norwegian). Lindholm M, Stordal F, Hessen DO, Moe SJ, Aass P. 2012. Climate 
driven range retraction of an Arctic freshwater crustacean. Freshwater Biology 57: 2591-2601. doi: 10.1111/fwb.12030

Lindholm M, Hessen DO, Færøvig PJ, Rognerud B, Andersen T, Stordal F. 2015. Is distribution of cold stenotherms constrained by temperature? The case of the Arctic fairy shrimp (Branchinecta palludosa O.F.Müller 1788). Journal of Thermal Biology 53 (2015): 46-52. doi: 10.1016/j.jtherbio.2015.08.005

Longhurst AR. 1955. Evolution in the notostraca. Evolution 9: 84-86.

Pedersen K, Scobie L. 1990. Dynamikk, habitatbruk og redskapsseleksjon for ørretbestanden i Kollsvatn, en innsjø på Hardangervidda. Norges landbrukshøgskole, Institutt for biologi og naturforvaltning. MSc thesis. 59 pp. (In Norwegian).

Presthus Heggen M, Birks HH, Anderson NJ. 2010. Longterm ecosystem dynamics of a small lake and its catchment in west Greenland. The Holocene 20(8): 1207-1222. doi: 10.1177/0959683610371995

Qvenild T, Rognerud S. 2018. Ørreten på Hardangervidda. Klimaets betydning for årsklassestyrke og produksjon av fisk og næringsdyr i Sandvatn 2001 - 2017. Norwegian Institute for Water Research (NIVA), Report L.NR. 7267-2018. 34 pp. (In Norwegian with an English summary).

Qvenild T, Fjeld E, Fjellheim A, Rognerud S, Tysse Å. 2018. Climatic effects on a cold stenotherm species Lepidurus arcticus (Branchiopoda, Notostraca) on the southern outreach of its distribution range. Fauna norvegica 38: 37-53. doi: 10.5324/ fn.v38i0.2598

Rognerud S, Borgstrøm R, Qvenild T, Tysse A. 2003. Ørreten på Hardangervidda. Norwegian Institute for Water Research (NIVA), Report L.NR. 4712-2003. 68 pp. (In Norwegian).

Rukke NA. 2002. Effects of low calcium concentrations on two common freshwater crustaceans, Gammarus lacustris and Astacus astacus. Freshwater Ecology 16: 357-366.

Simonsen TA, Valderhaug NA. 1994. Bestandsdynamikk, habitatbruk og ernæring for aure i Litlosvatn - en innsjø på Hardangervidda. Norges Landbrukshøgskole, Institutt for biologi og naturforvaltning. MSc thesis. 65 pp. (In Norwegian).

Skjelkvåle BL, Henriksen A. 1998. Water chemistry, acidification status and critical loads for national parks; Hardangervidda. Norwegian Institute for Water Research, Report L.NO. 3895-98: 49 pp. (In Norwegian with an English summary).

Sømme S. 1934. Contributions to the biology of Norwegian fish food animals I. Lepiduruas arcticus Pallas 1793. Avhandlinger utgitt av det Norske Videnskaps Akademi i Oslo. I. Matem.Naturvid. Klasse 1934. No 6: 1-36.

Sømme ID. 1941. Ørretboka. Jacob Dybwads Forlag. Oslo (1941). 591 pp. (In Norwegian).

Väinölä R, Könönen K, Lakka H-K, Uddström A, Mannerkoski I, Erkamo E, Arponen H, Keskinen E, Lanki M, Laine AO. 2019. Äyriäiset - Crustaceans - Crustacea. The 2019 Red List of Finnish Species. Ministry of the Environment \& Finnish Environment Institute. https:/www.researchgate.net/ publication/331838999_Ayriaiset__Crustaceans_-_Crustacea The_2019_Red_List_of_Finnish_Species

WalsengB,HalvorsenG,SChartauAKL. 1994. Ferskvannsbiologiske undersøkelser i Kvenna, 1978. Norsk institutt for naturforskning (NINA), Oppdragsmelding nr. 321-1994. 33 pp. (In Norwegian).

Walseng B, Raddum G, Saksgård R, Schartau AKL. 1996. Ferskvannsbiologiske undersøkelser i Kvenna 1995, med fokus på indikatorarter som redskap i forsuringsovervåkingen. Norwegian Institute for Nature Research (NINA), Oppdragsmelding 433.36 pp.

Økland KA, Økland J. 2003. Skjoldkrepsen Lepidurus arcticus i Norge. Fauna nr. 1-2003: 2-12. (In Norwegian with an English summary).

Editorial responsibility: Torkild Bakken.

This article is open-access and distributed under the terms of the Creative Commons Attribution 4.0 International license. This permits all non-commercial use, distribution, and reproduction in any medium, provided the original work is properly cited.

(http://creativecommons.org/licenses/by/4.0/). 


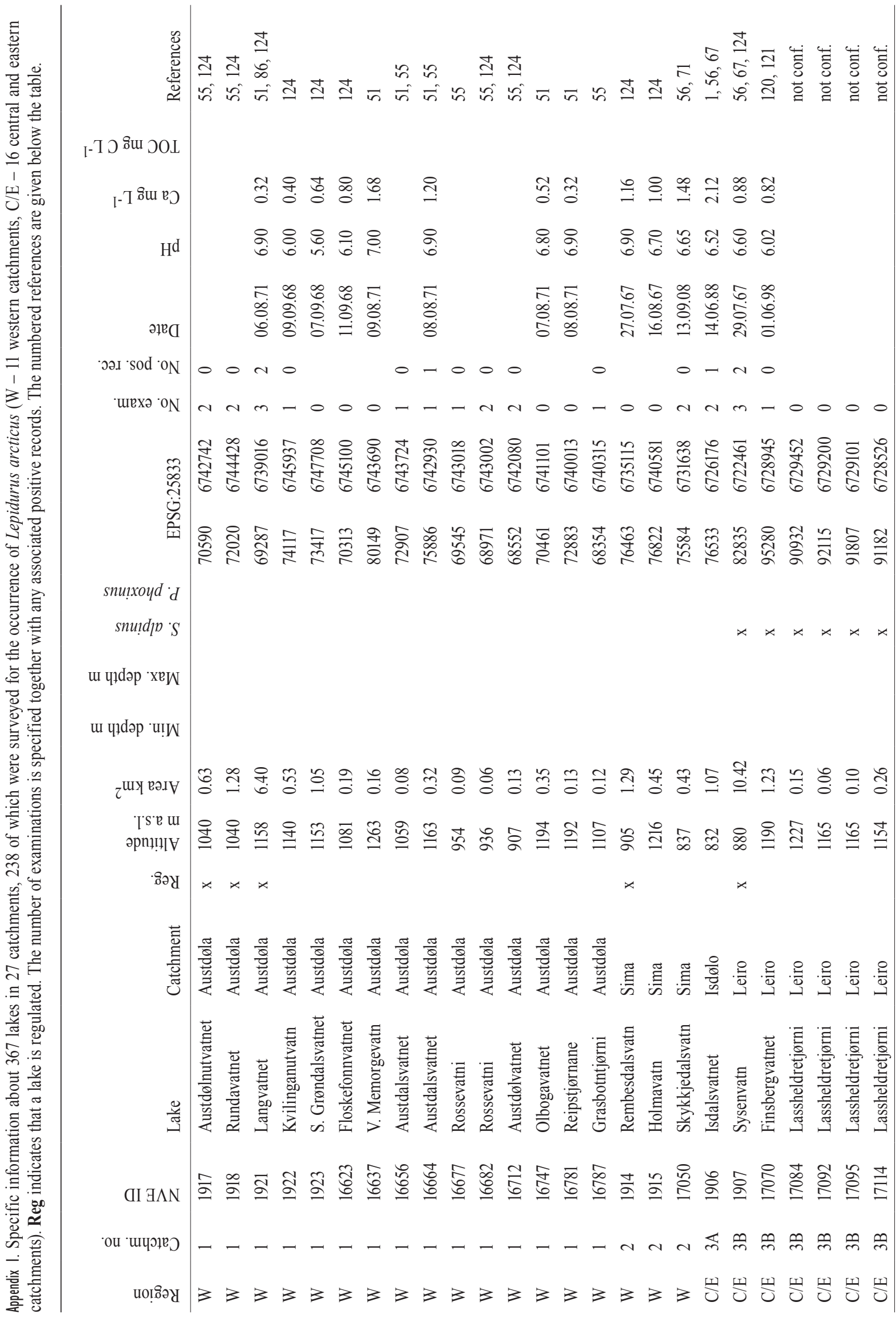




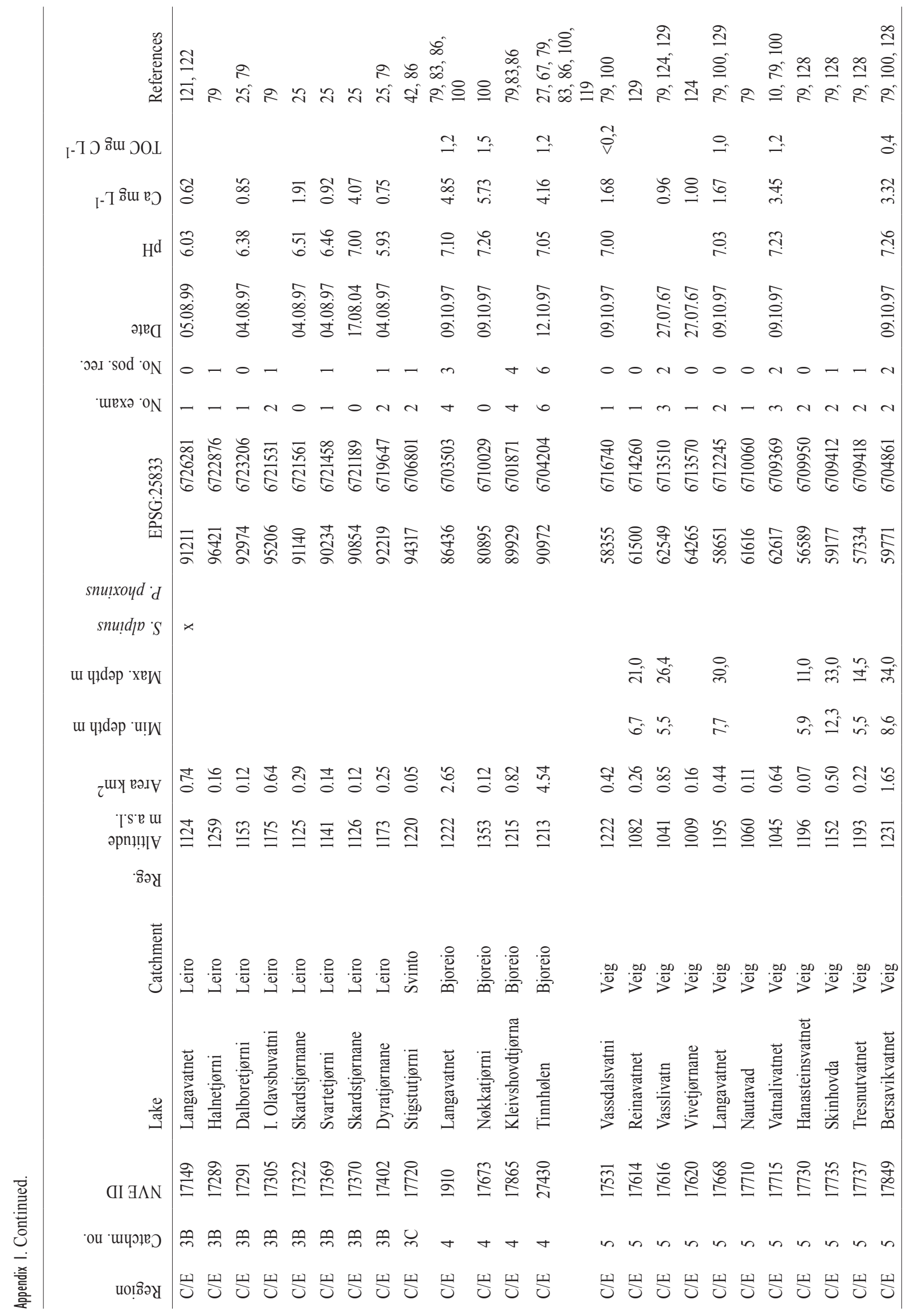




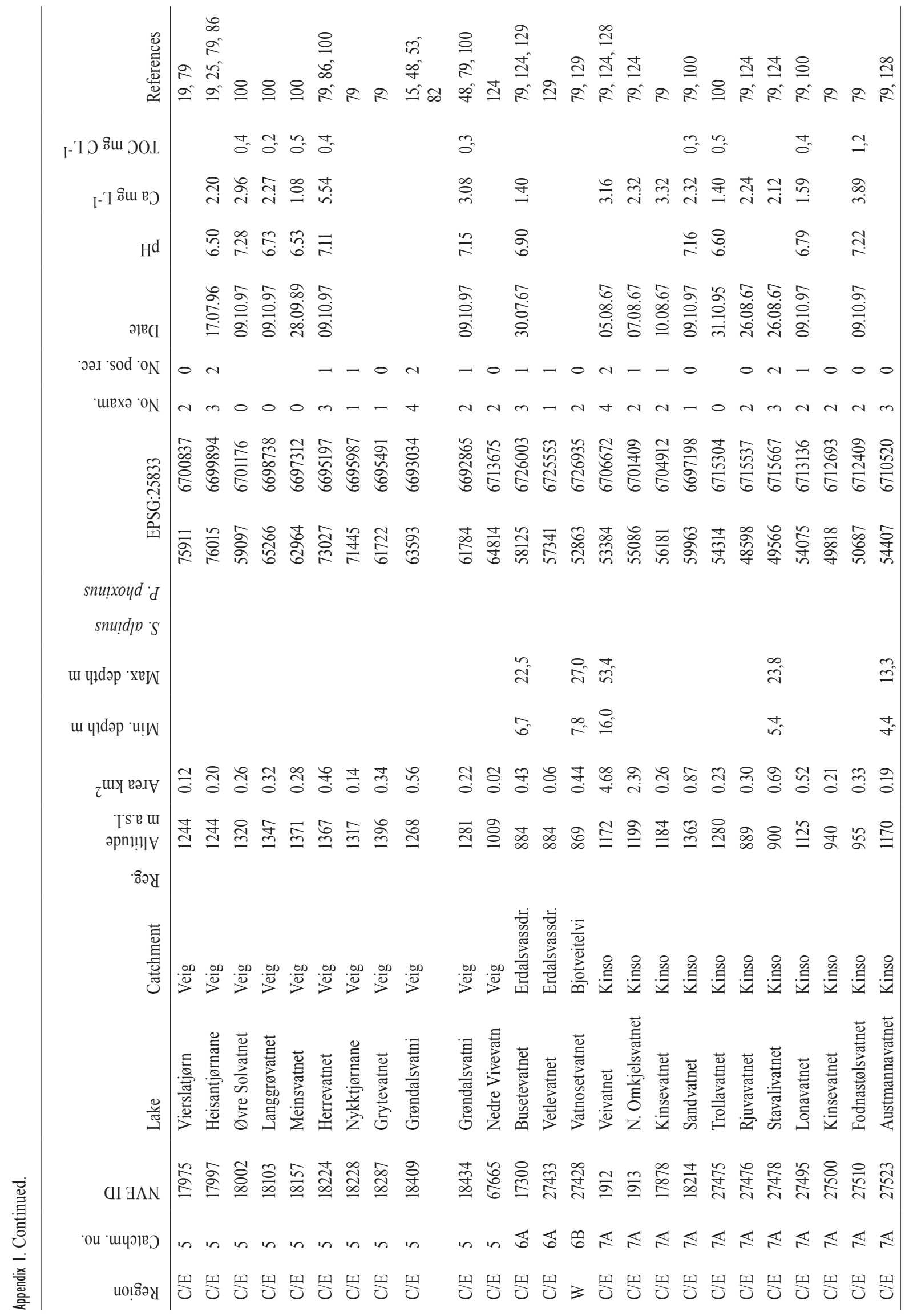




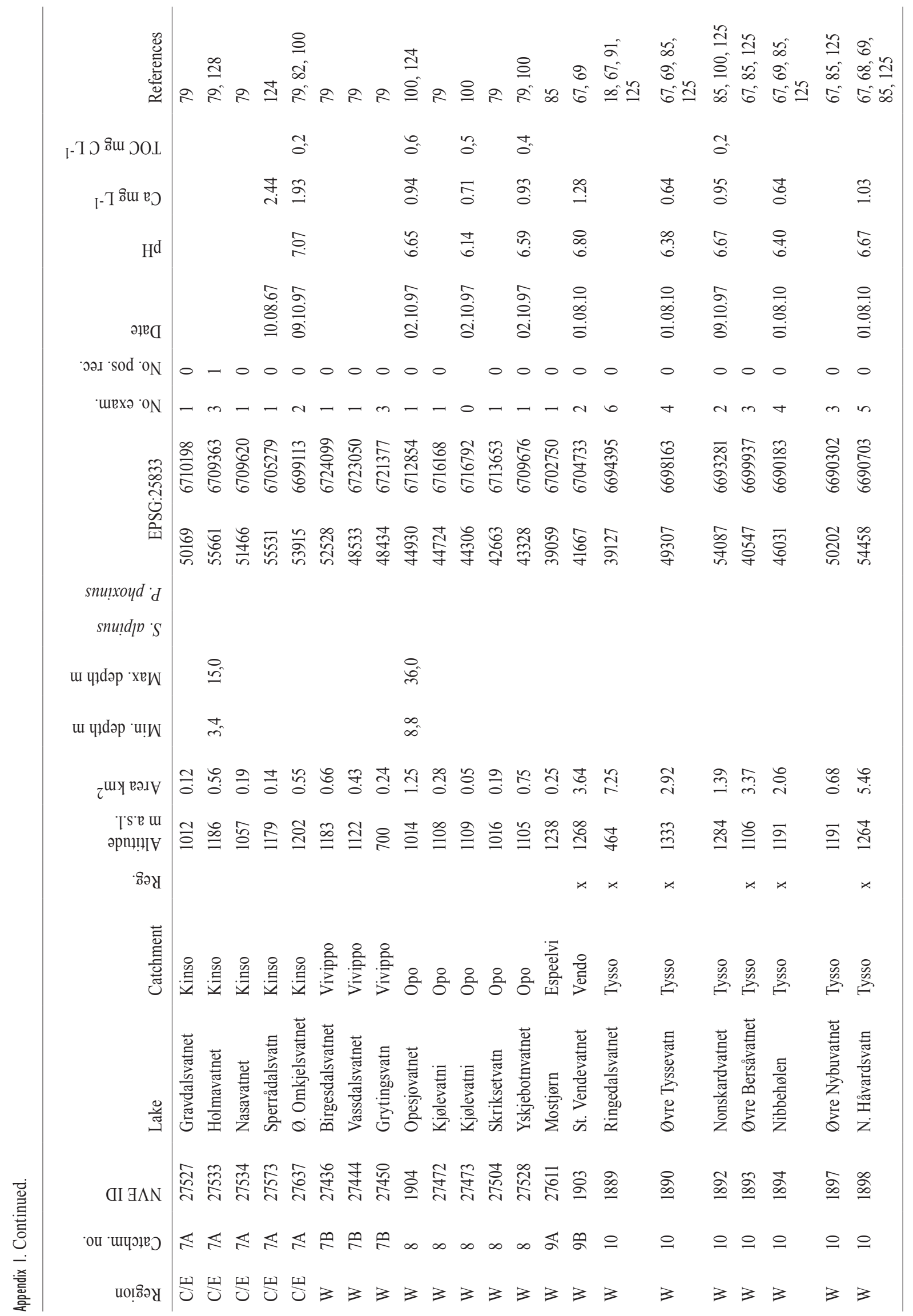




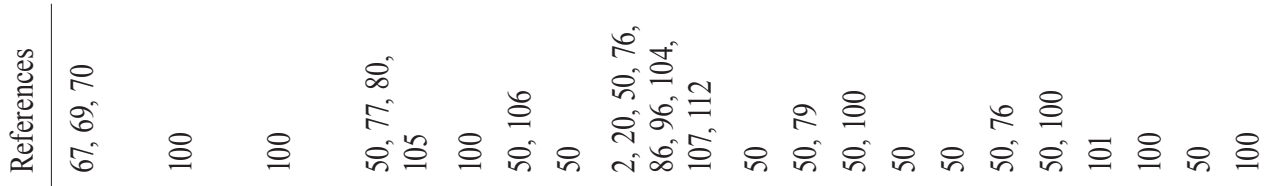

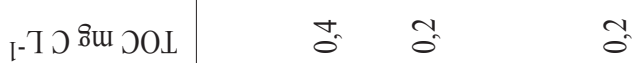

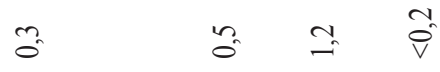

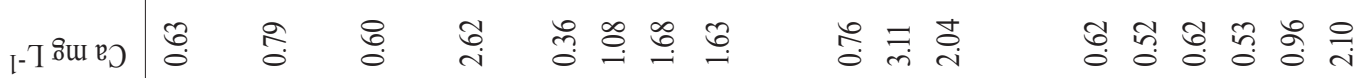

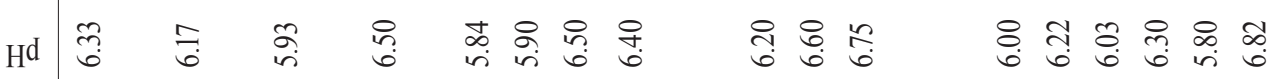

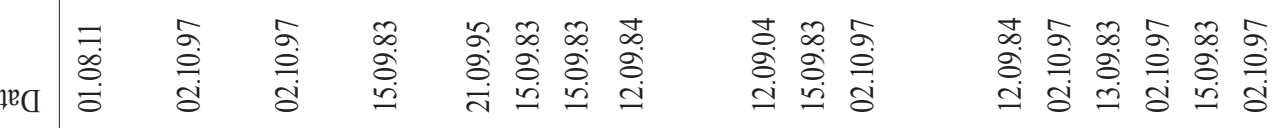
. כəa 'sod on 0

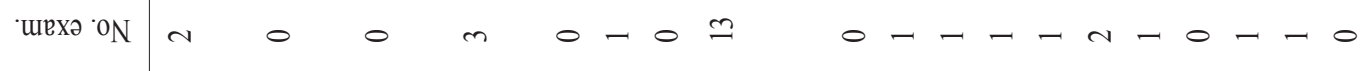

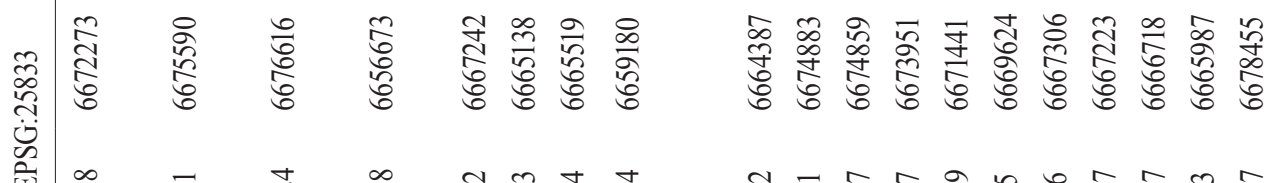

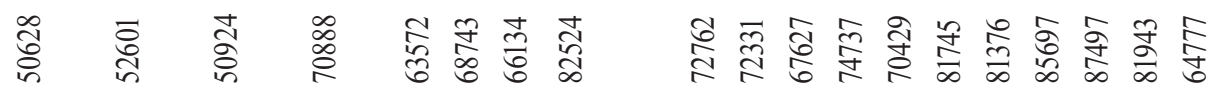

snu!xoyd $\cdot d$

snu!dpo $S$

ш цұdәр ·хеЏ

u بłdəp 'u!W

\begin{tabular}{|c|c|c|c|c|c|c|}
\hline wY & $\stackrel{\overbrace{}}{n}$ & $\stackrel{\infty}{0}$ & 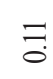 & oे. & 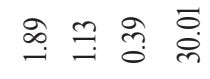 & 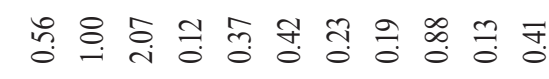 \\
\hline 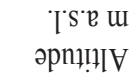 & $\stackrel{2}{i}$ & & ¿ & & 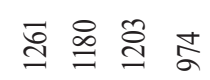 & ڤે \\
\hline
\end{tabular}

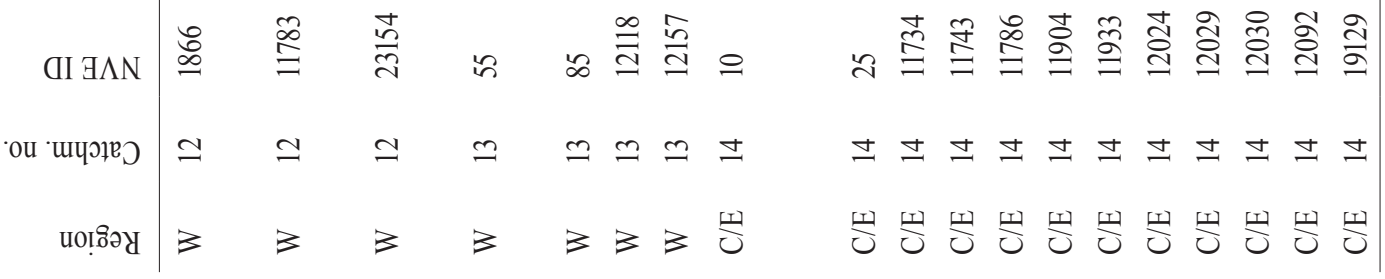




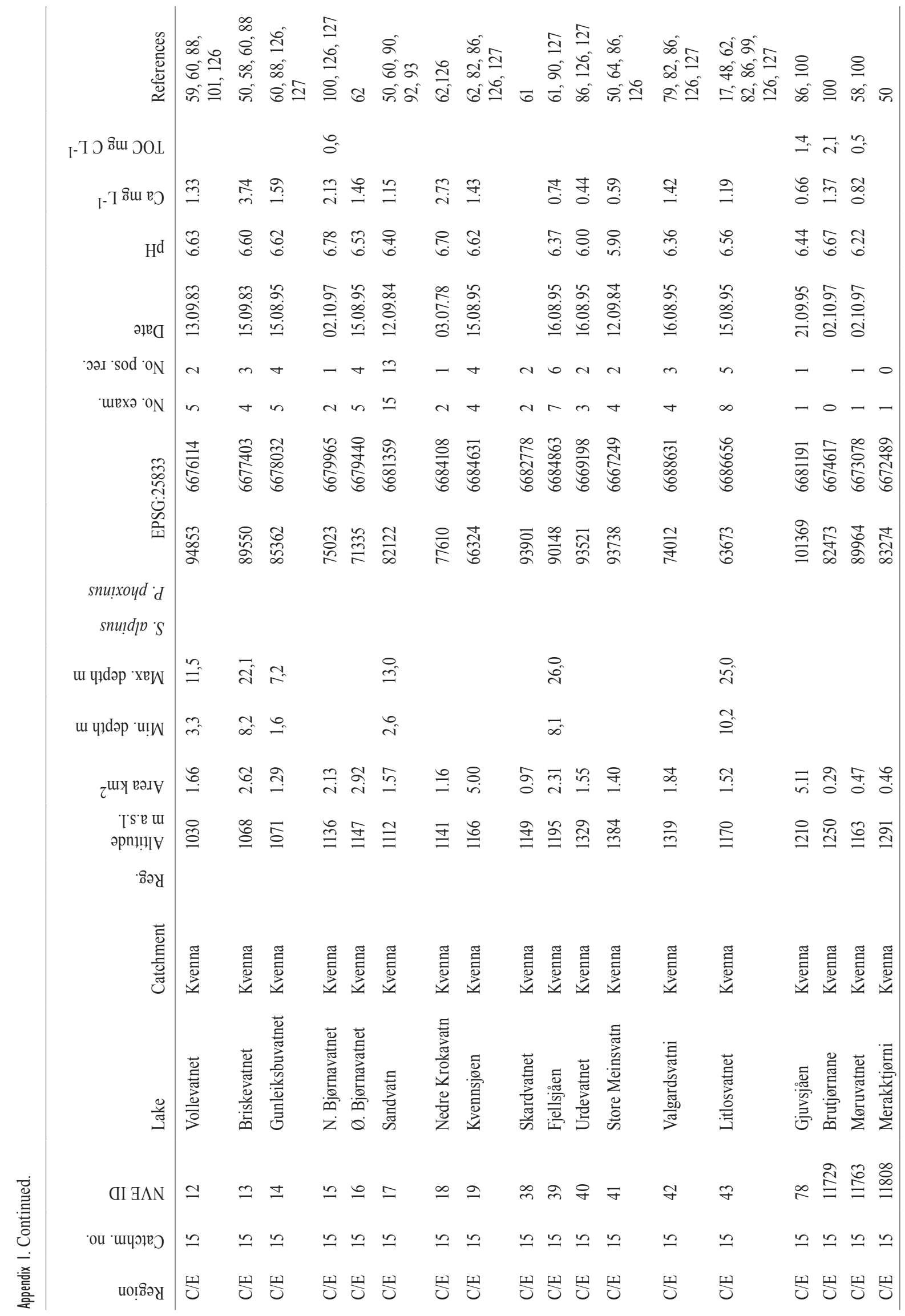




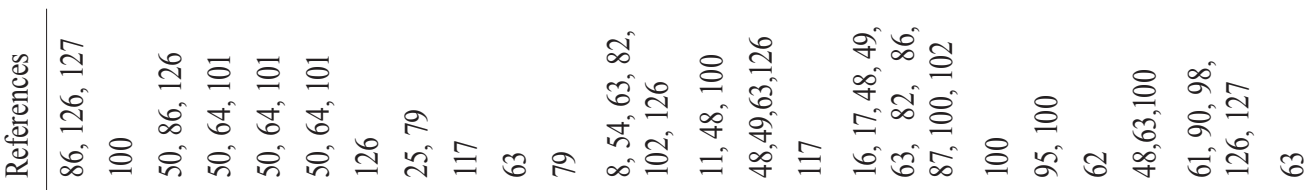

I-Tว ริน วOL

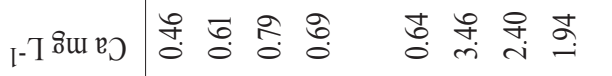

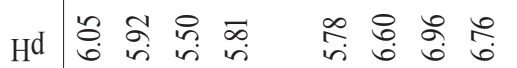

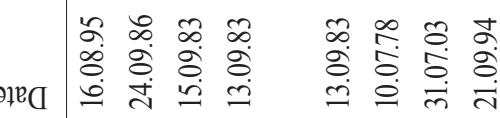
. 'யехә '0N

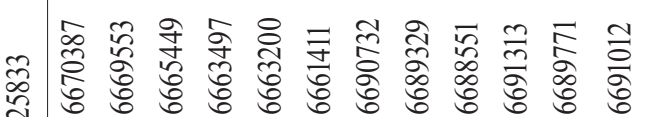
空

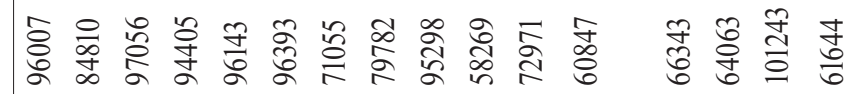
snu?xoyd $d$ snu!̣pls u чұdәр ·xש్ $\stackrel{8}{\circ} \stackrel{0}{9}$ u чұdәр 'ய!̣ $\tau^{\text {แY } 2 ว . \mathrm{IV}}$ กิ

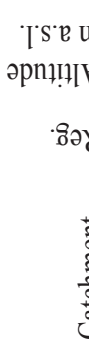

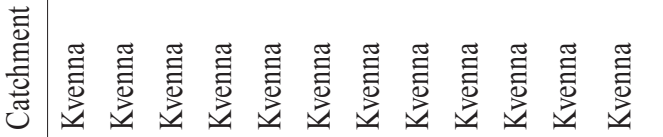

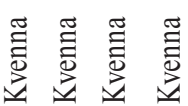
节节节节节节
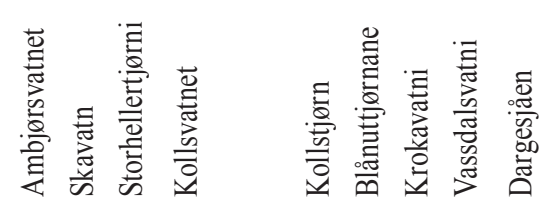

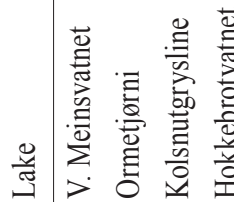

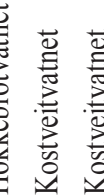

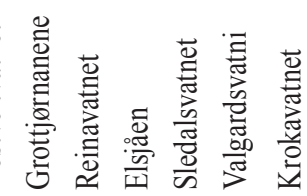

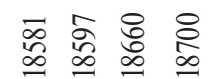

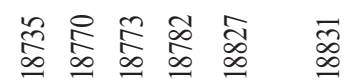
'ои 'นщэเ นо!ฺ̊ว

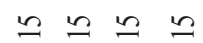

ஸ્山

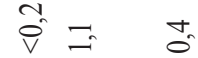

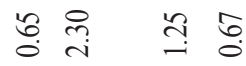

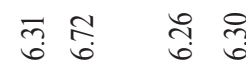

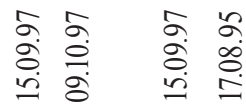




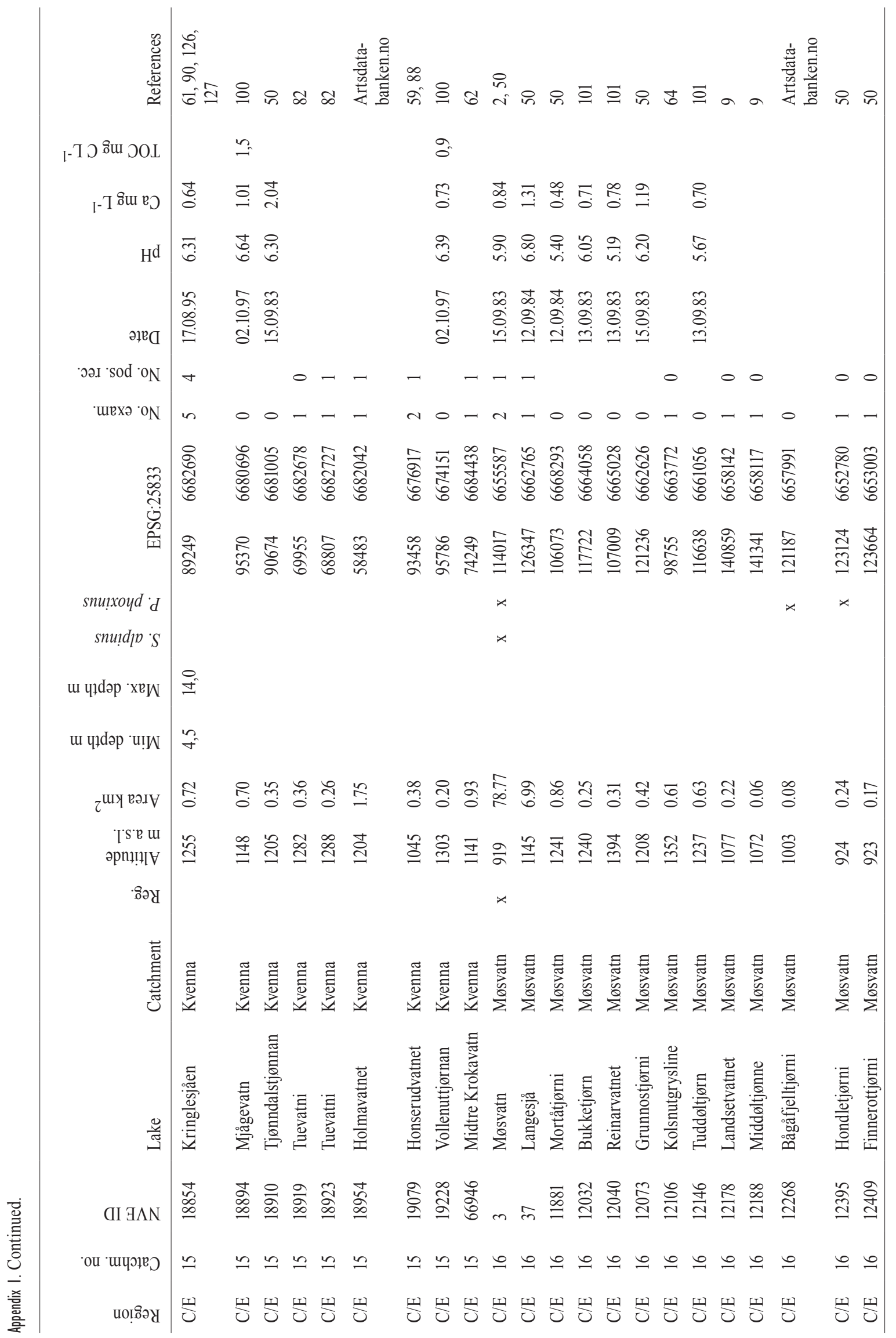




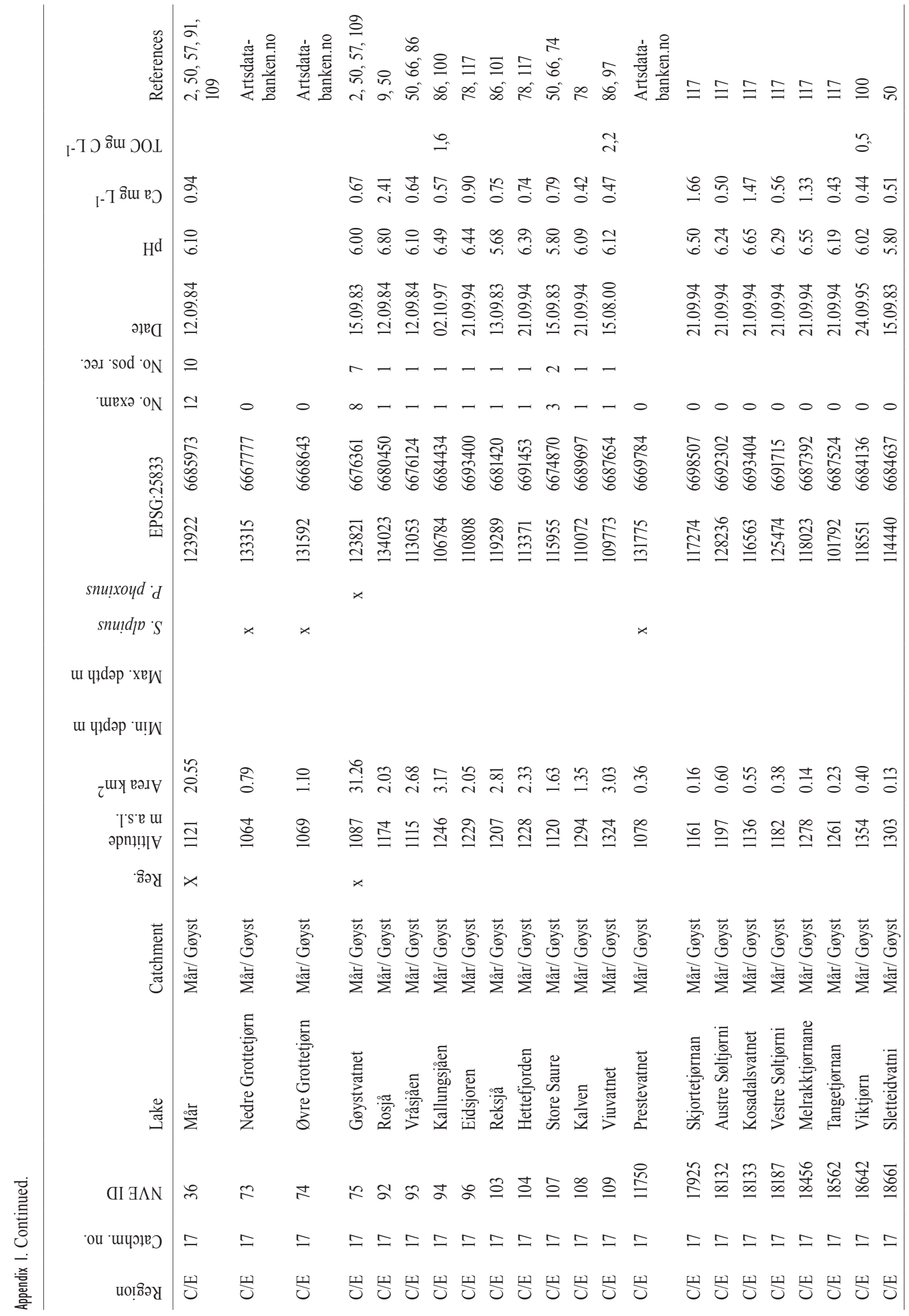




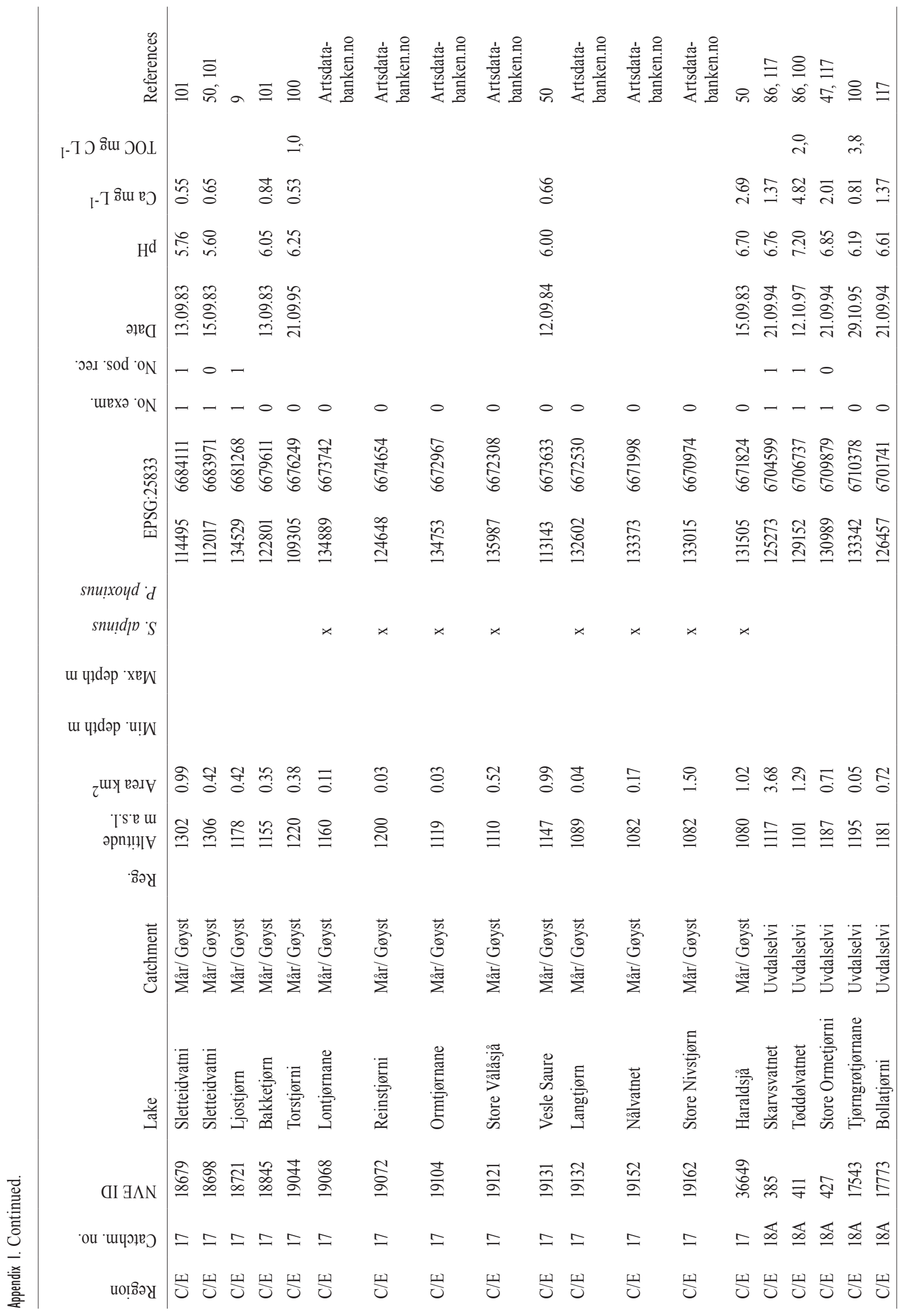




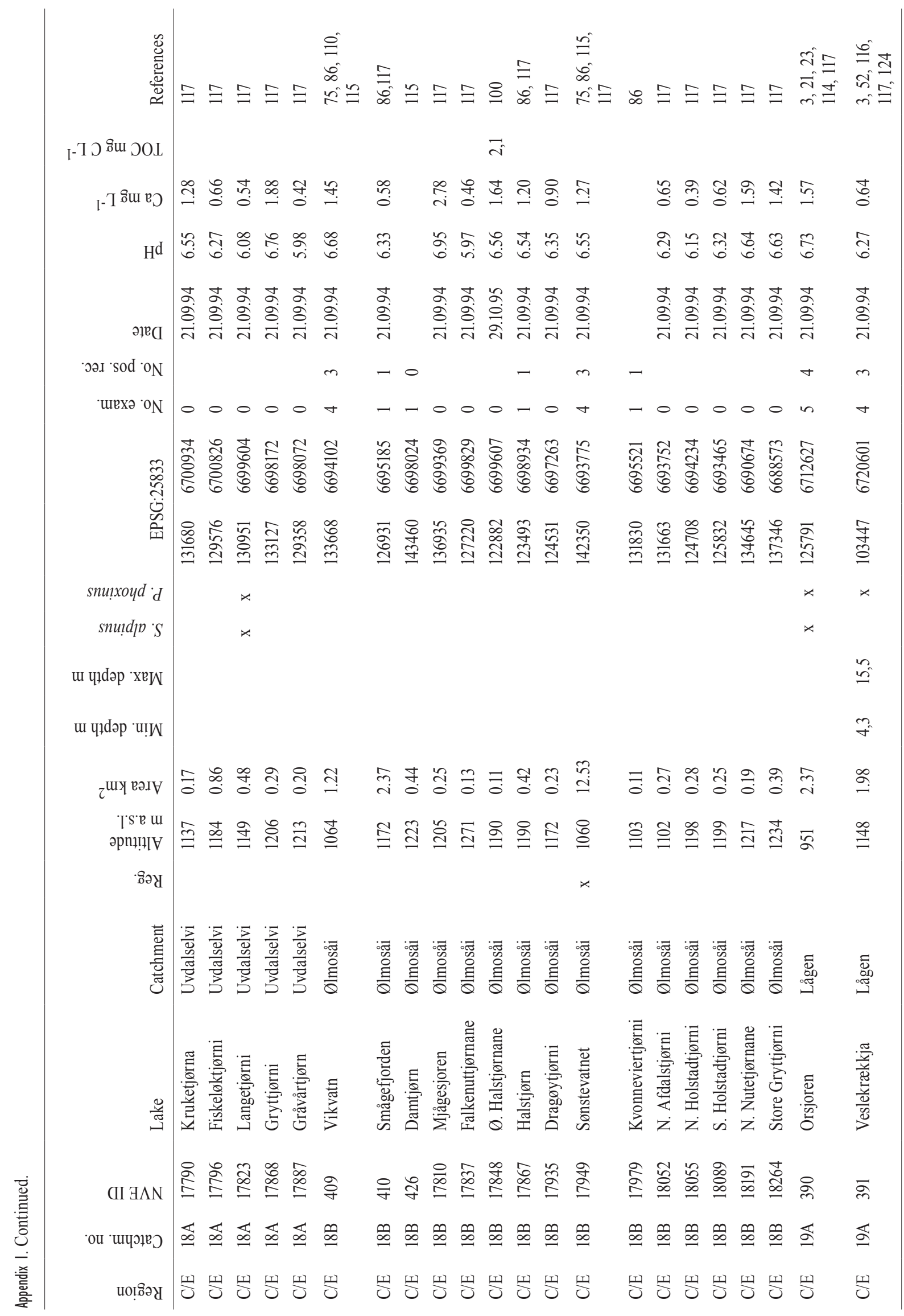




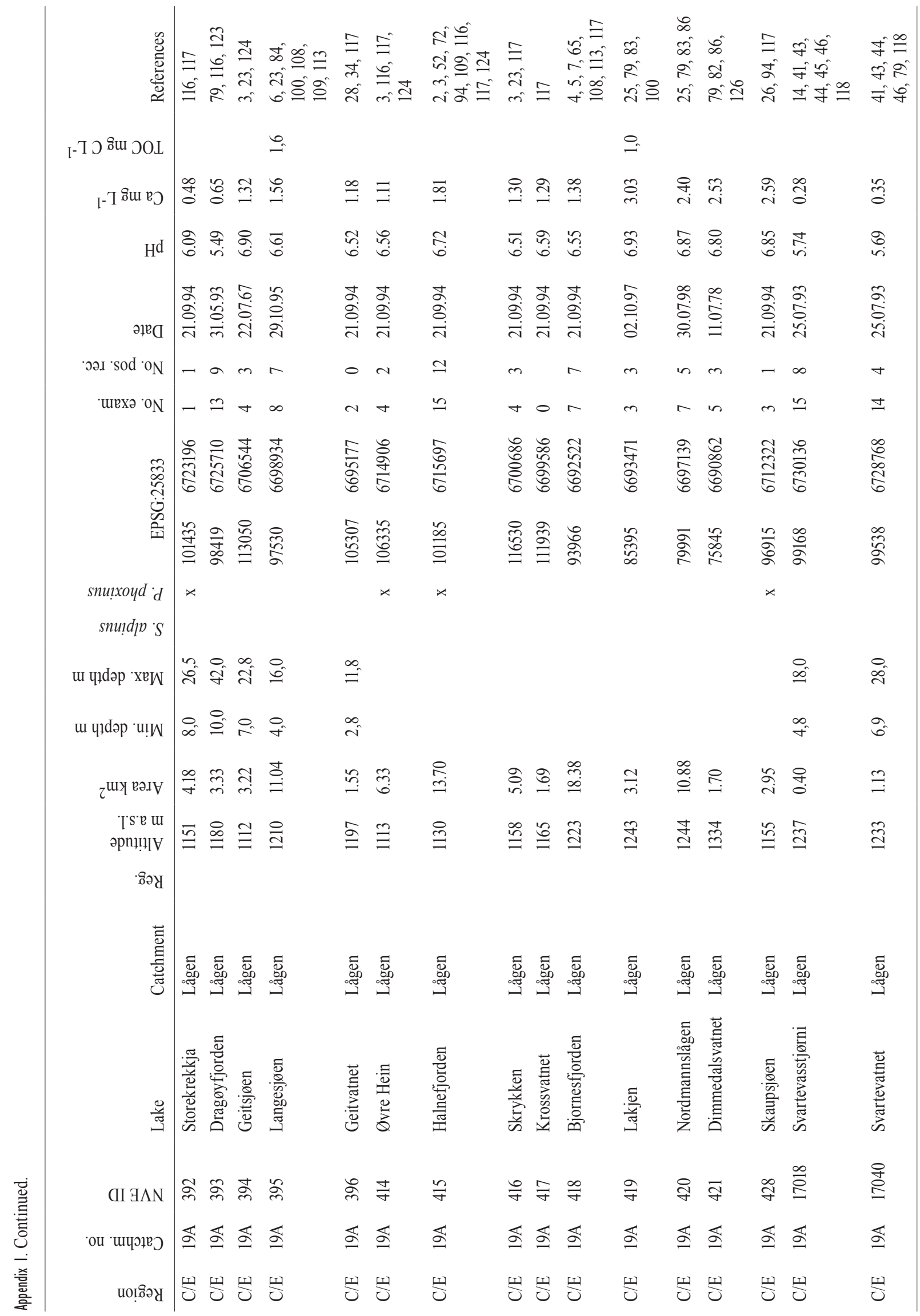




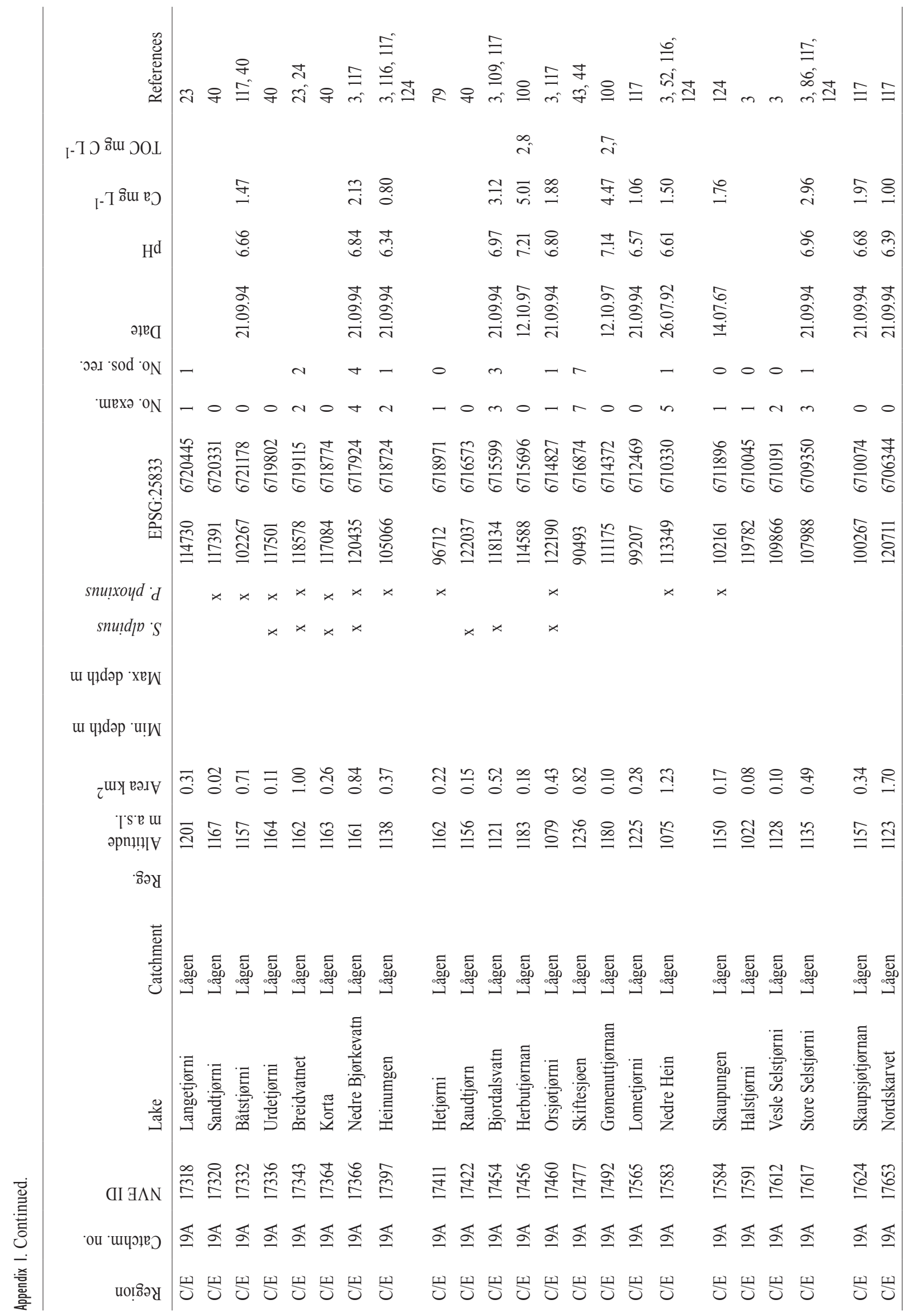




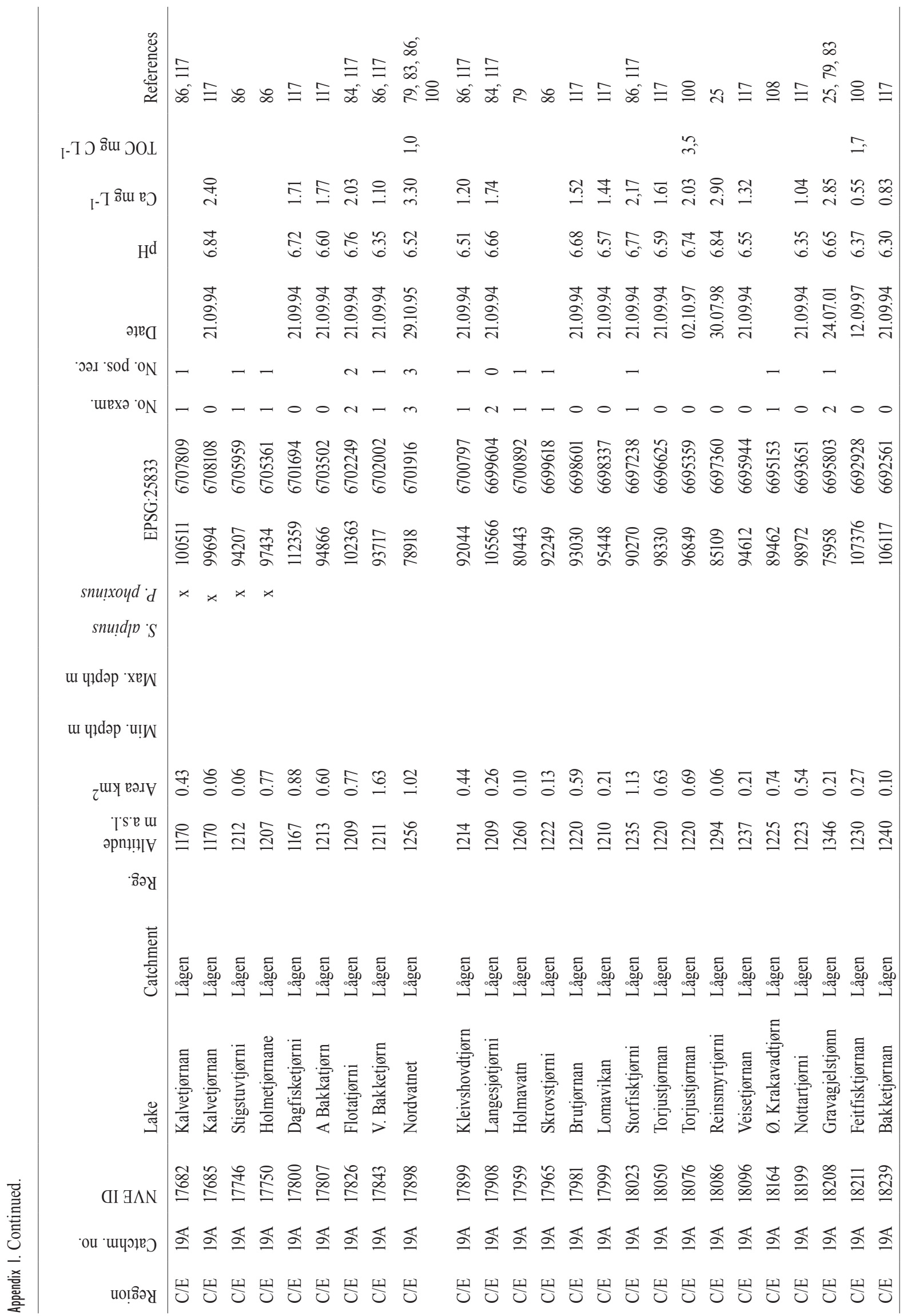




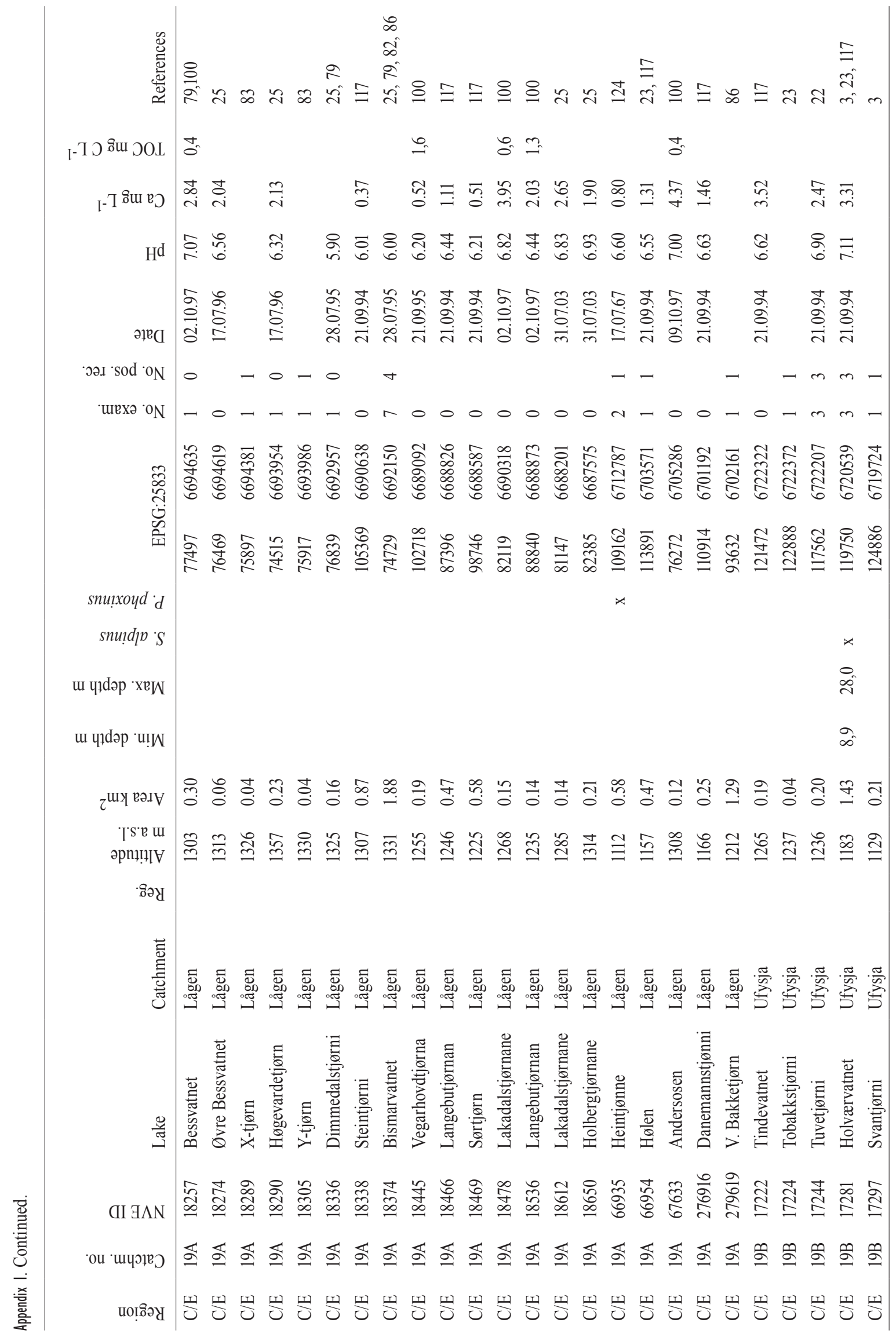




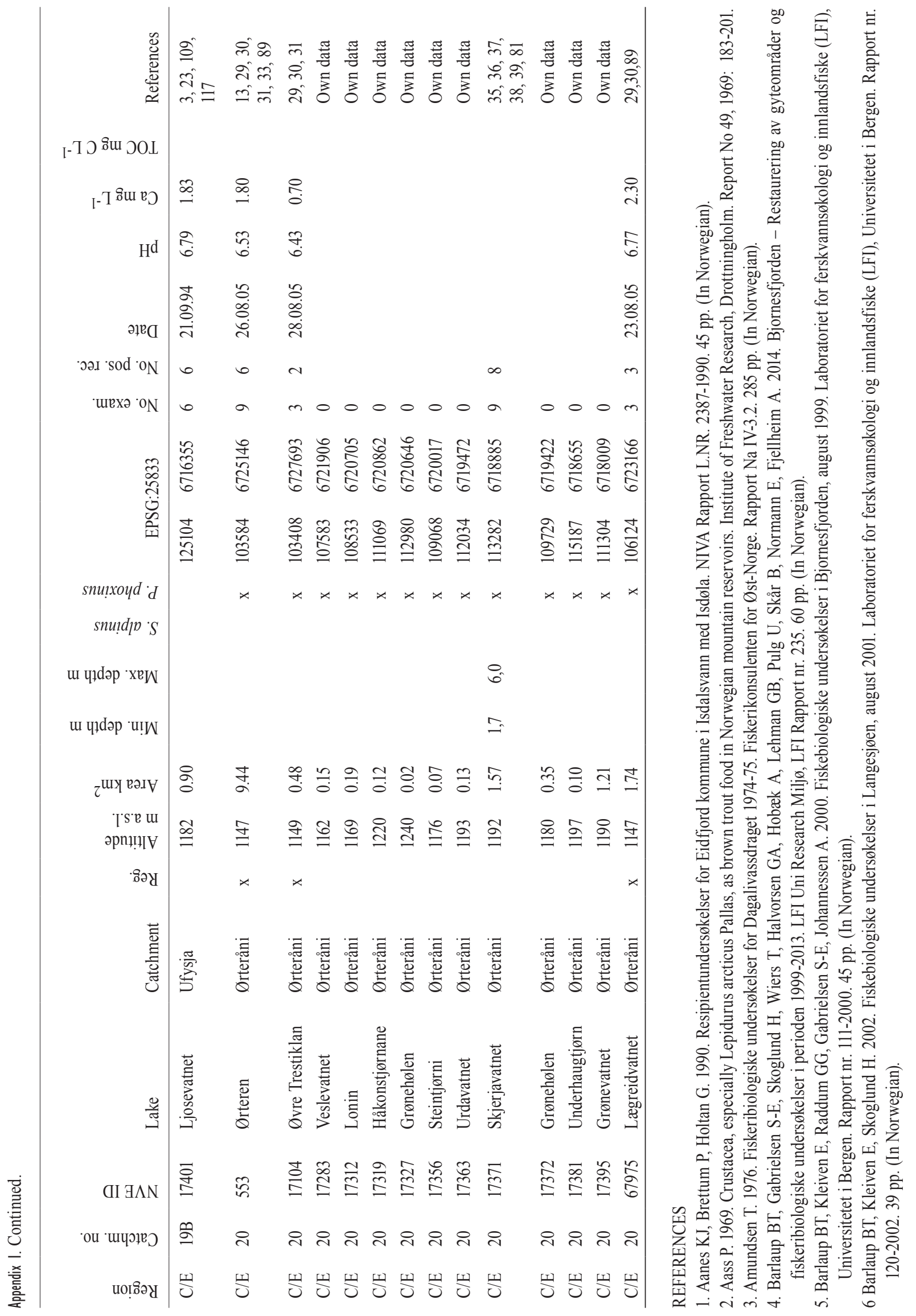



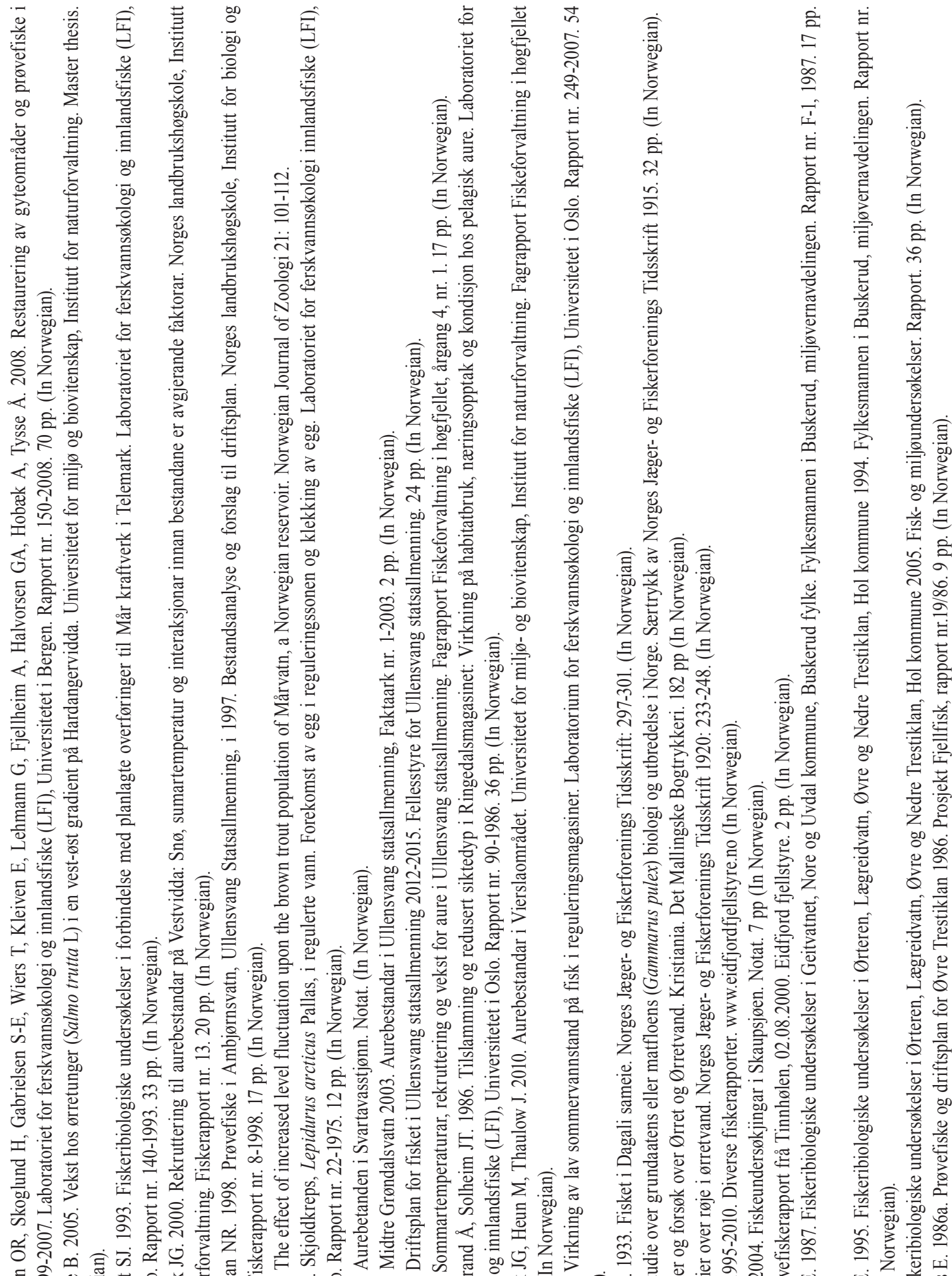

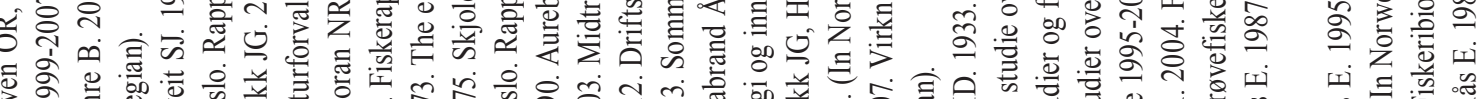

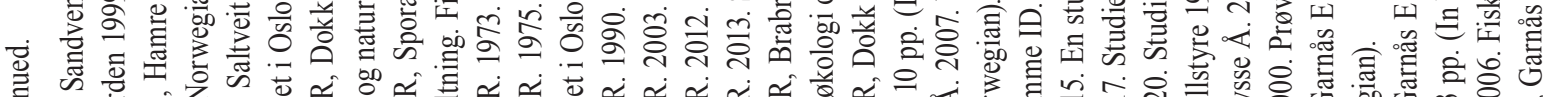

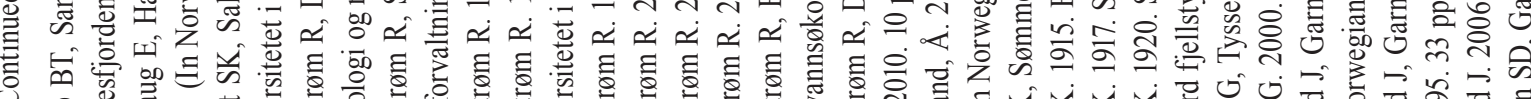

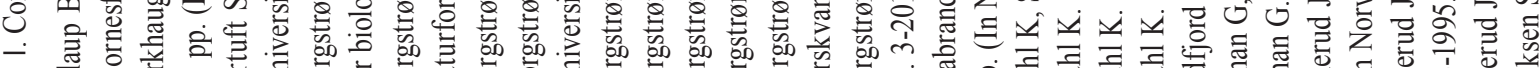

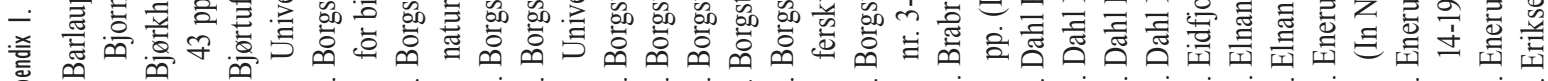

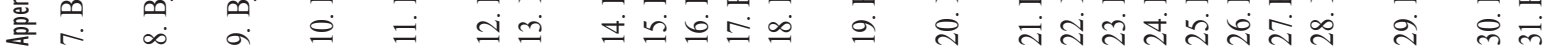




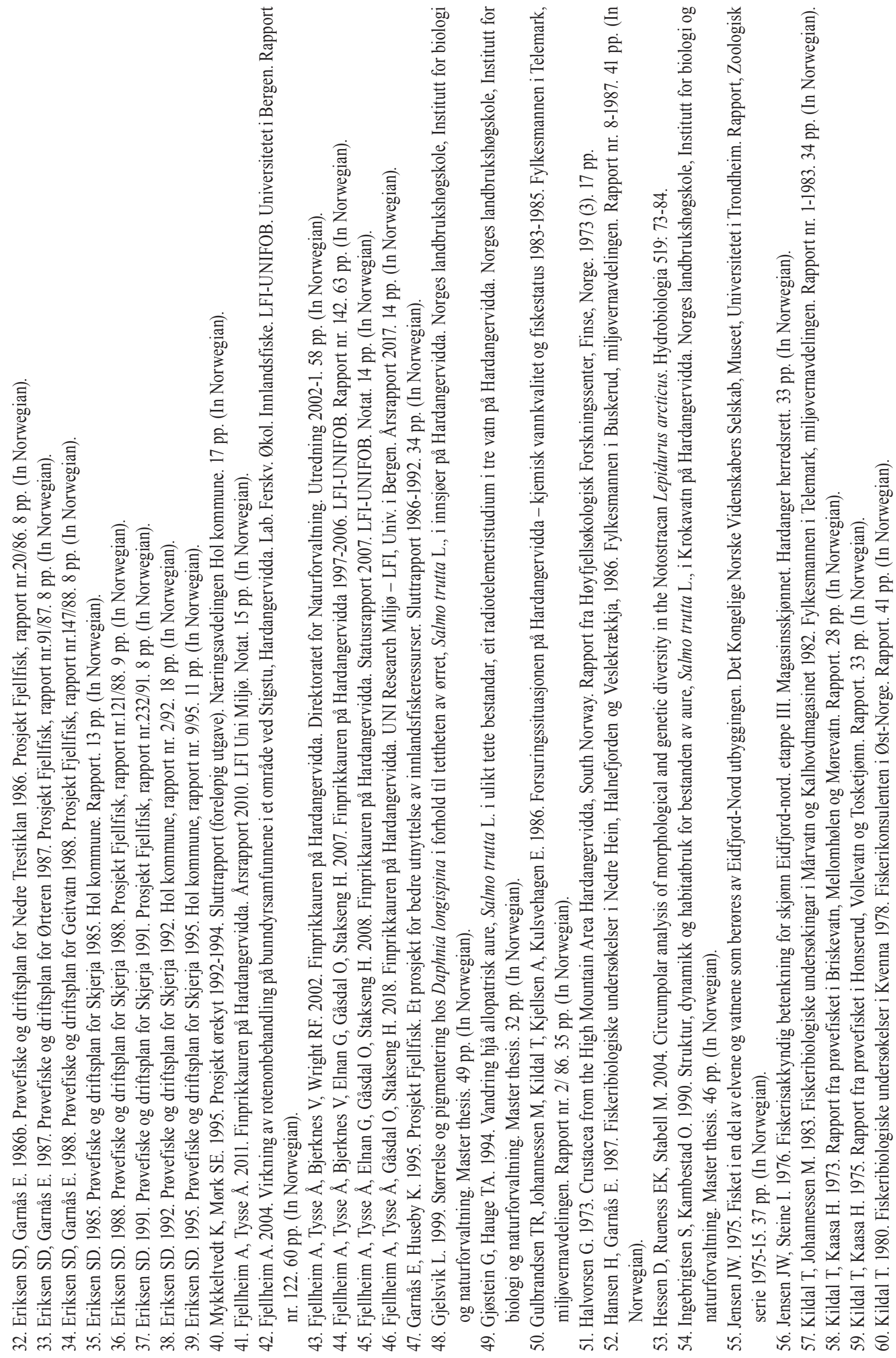




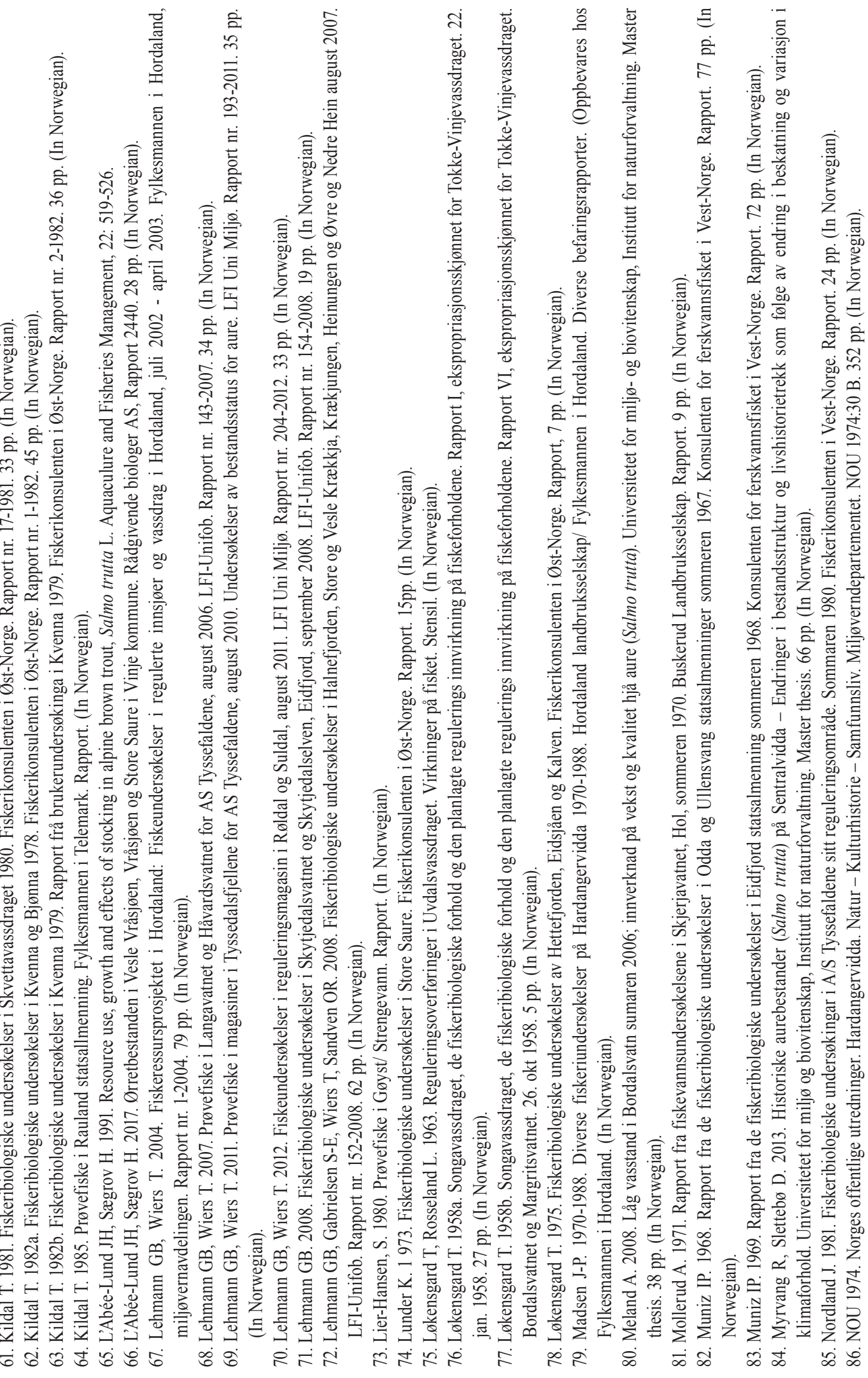




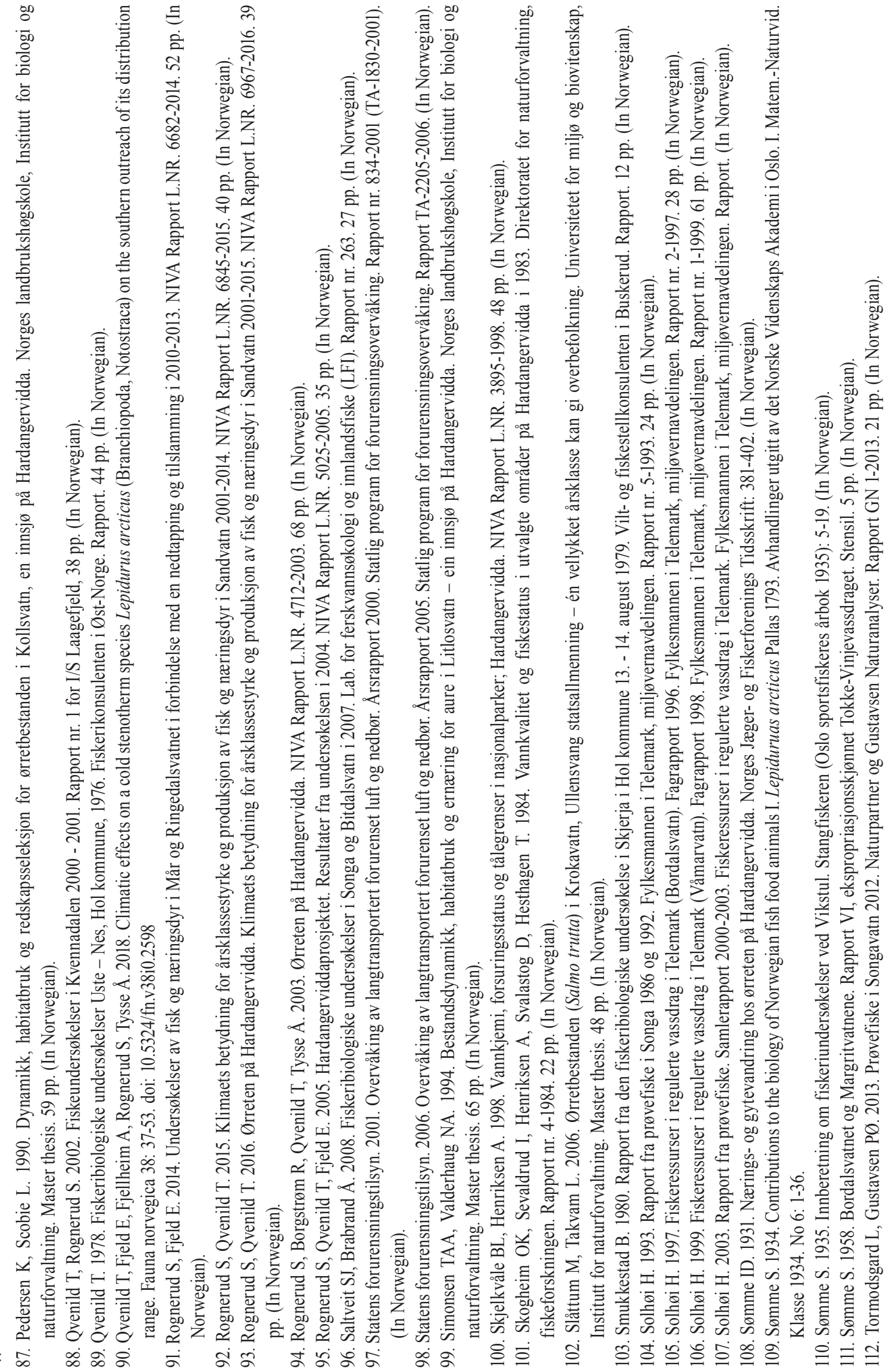



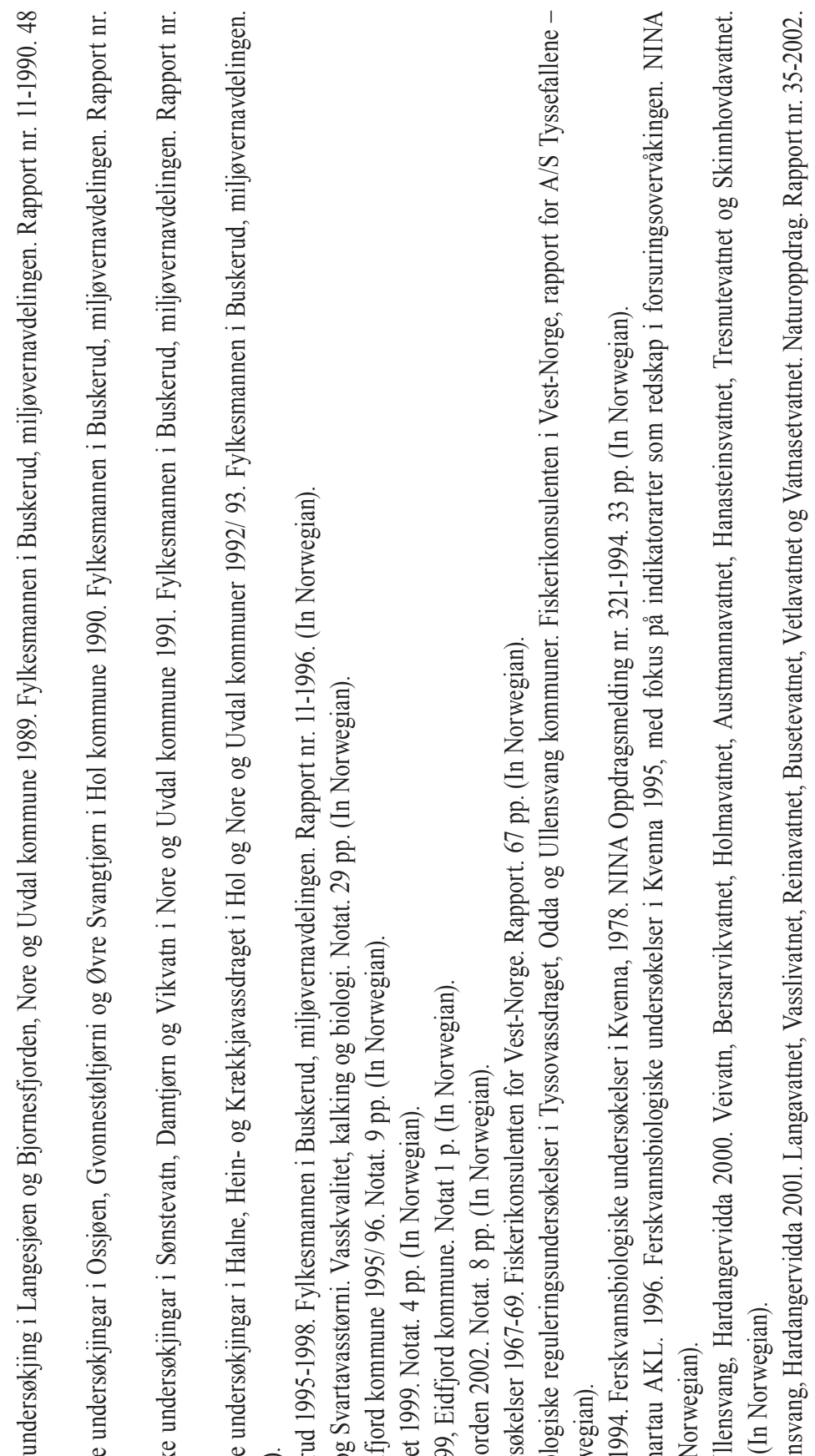

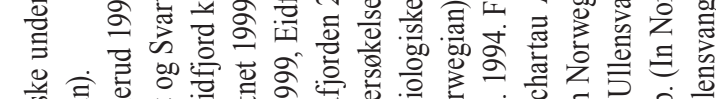

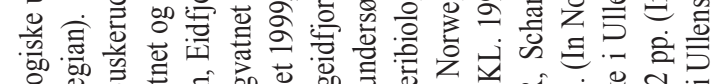
으유.

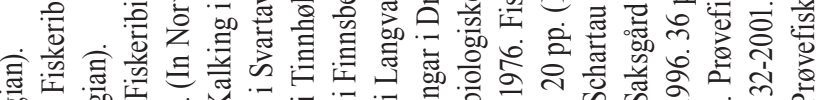
क्षे ठั

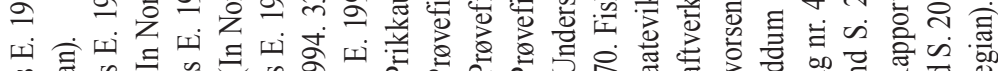

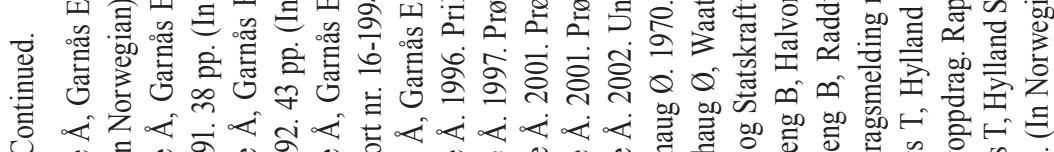

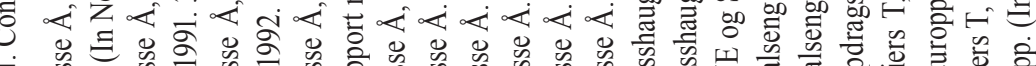

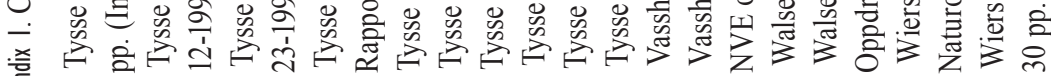
高音 新 